\title{
Gun jumping e manutenção de empregos como eficiência global da operação
}

\author{
Conselho Administrativo de Defesa Econômica (Cade)
}

\section{Ato de Concentração no 08700.010790/2015-41}

Requerentes: Banco Bradesco S.A. ("Bradesco"), HSBC Bank Brasil S.A. Banco Múltiplo e HSBC Serviços e Participações Ltda. ("HSBC")

Interessado: Sindicato dos Empregados em Estabelecimentos Bancários, Financiários e Empresas do Ramo Financeiro de Curitiba e Região ("Sindicato")

Advogados: Paulo Eduardo de Campos Lilla, Polliana Blans Libório, Eduardo Caminati Anders, Guilherme Teno Castilho Missali e outros.

\section{Voto}

(versão pública)

EMENTA: Ato de Concentração. Lei no 12.529/2011. Requerentes: HSBC Brasil e Banco Bradesco S.A. Produtos e serviços financeiros e não financeiros.

Sindicato admitido como Terceiro Interessado: denúncia de gun jumping e pedido de manutenção dos empregos como eficiência global da operação não acolhidos. 
Ambiente concorrencial caracterizado por elevada concentração, alto nível de rentabilidade e limitado grau de concorrência.

Mercado geográfico local. Preferência pela análise individualizada do mercado de produto em vez de análise por clusters. Sobreposição horizontal. Aplicação de filtros quantitativos de screening (UPP, GUPPI e CPPI). Possibilidade de exercício de poder de mercado. Elevadas barreiras à entrada, rivalidade limitada e incentivos ao exercício de poder coordenado. Probabilidade de exercício de poder de mercado. Nível de eficiências insuficiente para compensar provável elevação de preços.

Remédios comportamentais. Obrigação de "não comprar". Incentivo à portabilidade de crédito. Aprovação com restrições. Acordo em Controle de Concentrações (ACC).

Palavras chave: setor bancário - gun jumping - manutenção empregos - mercado local - UPP - GUPPI - CPPI - exercício de poder de mercado - eficiências insuficientes - ACC.

\section{Das requerentes}

1. O HSBC Brasil ("HSBC") pertence ao Grupo HSBC, uma organização de serviços financeiros e bancários com atuação mundial. O Grupo HSBC oferece a seus clientes uma ampla gama de produtos e serviços financeiros, tais como banco comercial, banco de investimentos e private banking, entre outros.

2. O Banco Bradesco S.A. ("Bradesco") é uma instituição financeira brasileira que oferta diversos produtos e serviços bancários e financeiros no Brasil e no exterior. Entre os produtos e serviços ofertados, encontram-se empréstimos e adiantamentos, depósitos, emissão de cartões de crédito, consórcios, seguros, arrendamento mercantil, comércio exterior, cobrança e processamento de pagamentos, planos de previdência complementar, gestão de ativos e serviços de intermediação e corretagem de valores mobiliários.

\section{Da operação}

3. A presente operação refere-se à aquisição de $100 \%$ do capital social do HSBC Bank Brasil S.A. - Banco Múltiplo e do HSBC Serviços e Participações Ltda. pelo Banco Bradesco S.A. 
4. De acordo com as Requerentes, a operação representa uma oportunidade para o Bradesco incrementar sua competitividade, com a melhora dos indicadores de eficiência e rentabilidade. Nesse sentido, ela possibilita ganho de escala e otimização de plataformas, com aumento da cobertura nacional, além de reforçar sua presença no segmento de alta renda. A aquisição permitirá também a expansão das operações do Bradesco, especialmente nos segmentos de seguros, cartão de crédito e administração de fundos.

5. No que diz respeito ao HSBC, a venda decorre do realinhamento estratégico em execução pelo Grupo. Em virtude das dificuldades de superação do problema de escala e inviabilidade de crescimento orgânico nos patamares projetados pelo Grupo, decidiu-se pela venda das operações no Brasil e no foco ao atendimento de seus clientes internacionais.

6. A composição acionária do HSBC, quando da apresentação da presente operação ao Cade, encontra-se descrita no quadro abaixo: ${ }^{1}$

Quadro 1

Composição do Capital Social do HSBC Bank Brasil S.A. - Banco Múltiplo

\begin{tabular}{|l|r|}
\hline \multicolumn{1}{|c|}{ Acionista } & $\begin{array}{c}\text { Participação no } \\
\text { capital social }\end{array}$ \\
\hline HSBC Latin America Holding (UK) Limited & 99,99999996 \\
\hline HSBC Investment Bank Holdings BV (Holanda) & 0,00000004 \\
\hline Total & 100 \\
\hline
\end{tabular}

Fonte: Elaboração da Superintendência-Geral, com base em dados apresentados pelas requerentes no Anexo 1.

Quadro 2

Composição do Capital Social do HSBC Serviços e Participações Ltda.

\begin{tabular}{|l|r|}
\hline \multicolumn{1}{|c|}{ Acionista } & $\begin{array}{r}\text { Participação no } \\
\text { capital social }\end{array}$ \\
\hline HSBC Bank Brasil S/A - Banco Múltiplo & 99,98 \\
\hline HSBC Investment Bank Holdings BV (Holanda) & 0,012612 \\
\hline Total & 100 \\
\hline
\end{tabular}

Fonte: Elaboração da Superintendência-Geral, com base em dados apresentados pelas requerentes no Anexo 1.

1 Anexo ao Parecer Técnico no 12/2016/CGAA02/SGA1/SG/CADE (SEI 0183985). 
7. A composição acionária do Bradesco, quando da apresentação da presente operação ao Cade, encontra-se descrita no quadro abaixo: ${ }^{2}$

Quadro 3

Composição do Capital Social do Bradesco

\begin{tabular}{|l|r|}
\hline \multicolumn{1}{|c|}{ Acionista } & $\begin{array}{c}\text { Participação no } \\
\text { capital social }\end{array}$ \\
\hline Cidade de Deus - Companhia Comercial de Participações & 47,6 \\
\hline Fundação Bradesco & 17,04 \\
\hline NCF Participações & 8,2 \\
\hline Outros & 27,16 \\
\hline Total & 100 \\
\hline
\end{tabular}

Fonte: Elaboração da Superintendência-Geral, com base no Documento SEI nং 0126376.

8. Quanto aos aspectos formais da operação, a Superintendência-Geral apresentou as seguintes informações: ${ }^{3}$

\section{Quadro 4}

Aspectos Formais da Operação

\begin{tabular}{|c|c|}
\hline $\begin{array}{c}\text { Operação foi } \\
\text { conhecida? }\end{array}$ & $\begin{array}{c}\text { Sim - Os faturamentos dos Grupos envolvidos foram superiores a } \\
\text { R } \$ 750 \text { milhões no ano de } 2014 .\end{array}$ \\
\hline $\begin{array}{c}\text { Taxa processual } \\
\text { foi recolhida? }\end{array}$ & Sim (documento SEI n $\left.{ }^{\circ} 0126365\right)$. \\
\hline $\begin{array}{c}\text { Data de } \\
\text { publicação do } \\
\text { edital }\end{array}$ & $\begin{array}{r}\text { O Edital } n^{\circ} 376 / 2015 \text {, que deu publicidade à operação em análise, } \\
\text { foi publicado no dia 09/11/2015 }\end{array}$ \\
\hline $\begin{array}{c}\text { Data da } \\
\text { notificação ou } \\
\text { emenda }\end{array}$ & 27 de outubro de 2015 \\
\hline
\end{tabular}

9. Portanto, considero que foram atendidas as exigências formais para apresentação da operação a este Conselho.

2 Anexo ao Parecer Técnico no 12/2016/CGAA02/SGA1/SG/CADE (SEI 0183985).

3 Anexo ao Parecer Técnico no 12/2016/CGAA02/SGA1/SG/CADE (SEI 0183985). 


\section{Do terceiro interessado}

10. Após a publicação do Edital, em 24 de novembro de 2015, o Sindicato dos Empregados em Estabelecimentos Bancários, Financiários e Empresas do Ramo Financeiro de Curitiba e Região ("Sindicato") solicitou sua habilitação nos autos como terceiro interessado. O pedido foi justificado em informações e documentos que demonstrariam uma possível consumação antecipada da operação e, ainda, que a concentração teria impactos concorrenciais relevantes em diversos municípios do estado do Paraná, onde o HSBC mantém sua sede, sendo necessária a manutenção dos atuais níveis de emprego (vide documento SEI 0144244).

11. Por meio do Despacho no $1464 / 2015,{ }^{4}$ de 27 de novembro de 2015, a SG deferiu o pedido de ingresso do Sindicato como terceiro interessado.

12. Primeiramente, saúdo aqui a presença dos representantes do sindicato dos empregados, que fizeram uso legítimo de seu direito à sustentação oral para trazer ao plenário suas preocupações. Reforço a importância de terceiros interessados nos processos de atos de concentração, pois enriquecem a análise e reduzem a forte assimetria de informação entre regulador e regulado.

13. Em relação à alegação de consumação antecipada da operação gun jumping, o Sindicato argumentou que a demissão de funcionários da HDI Seguros poderia indicar encerramento prematuro das atividades entre essa seguradora e o HSBC, além de ter apresentado alguns documentos que, no seu entendimento, demonstrariam que as Requerentes já estariam atuando como uma única instituição. Os documentos referem-se a e-mails com instruções para recebimento de arquivos do Bradesco e com alterações nos procedimentos rotineiros bem como telas de sistemas que indicariam a unificação da estrutura de Tecnologia da Informação.

14. Ainda em relação a uma possível consumação prematura da operação e com o objetivo de permitir um melhor acompanhamento pela SG, em 3 de novembro de 2015, foi enviado o Ofício 6083/2015/CADE ao Bradesco com solicitação de esclarecimentos sobre notícias veiculadas na imprensa e identificação de equipes e processos de transição que estariam em andamento.

15. No Parecer Técnico no 12/2016, por meio do qual a SuperintendênciaGeral faz a análise da operação e explicita sua recomendação a esse Tribunal,

4 Acolheu a Nota Técnica no 88/2015/CGAA2/SGA1/SG/CADE. 
consta a avaliação de que os documentos apresentados pelo Terceiro Interessado não seriam hábeis para configurar gun jumping, que as imagens acostadas aos autos se referem, aparentemente, a testes e validações de procedimentos que não podem ser classificados como ingerência indevida da adquirente sobre a adquirida.

16. Por fim, em 6 de maio de 2016, o Sindicato apresentou Alegações Finais, na qual pugna ao Tribunal que analise e se manifeste acerca de seu pleito de "manutenção de empregos e eficiência global da operação" e, assim, ou (i) reprove a operação ou (ii) a aprove com a manutenção integral do nível atual de empregos mantidos pelas Requerentes. Em pedido subsidiário, requer, ao menos, a manutenção das atividades e empregos da empresa de TI mantida, atualmente, pelo HSBC.

\section{III.1 Da Possível Violação do Art. 88, \$\$3o e 40, da Lei 12.529 - gun jumping}

17. Em relação à suposta ocorrência de gun jumping, adianto, desde já, que concordo com a avaliação realizada pela SG e a incorporo nas minhas razões de decidir.

18. O conjunto de informações trazidas aos autos não são suficientes para provar uma consumação antecipada da operação. Não há provas, por exemplo, de que a demissão de funcionários da HDI Seguros teria sido uma iniciativa do Bradesco. Sequer há provas das supostas demissões e/ou da sua amplitude, o que poderia indicar eventual influência do Bradesco sobre as atividades da referida empresa. Processos de contratação e demissão fazem parte da rotina de qualquer instituição privada, assim, seria inadequada qualquer exigência no sentido de que, durante o processo de análise do órgão antitruste, o que pode levar até 330 dias, as empresas envolvidas no ato de concentração fossem impedidas de contratar ou demitir empregados.

19. OCADE, objetivando dar maior segurançajurídica aosjurisdicionados, elaborou o Guia para Análise da Consumação Prévia de Atos de Concentração Econômica, contendo informações objetivas do que pode ser considerado gun jumping e como as partes podem se preservar durante o processo de análise. Segundo o Guia, as atividades que levantam preocupações podem ser divididas em três grupos: (i) troca de informações concorrencialmente sensíveis entre os agentes econômicos envolvidos; (ii) definição de cláusulas 
contratuais que regem a relação entre os agentes econômicos; e (iii) atividades das partes antes e durante a implementação do ato de concentração.

20. Claramente, as supostas evidências juntadas aos autos não demonstram a troca de informações concorrencialmente sensíveis tampouco a existência de cláusulas contratuais que regeriam a relação entre o Bradesco e o HSBC. É preciso observar, contudo, o terceiro item, que trata das atividades das partes antes e durante a implementação do ato de concentração. Nos termos do Guia, podem configurar consumação antecipada da operação:

(i) transferência e/ou usufruto de ativos em geral (inclusive de valores mobiliários com direito a voto);

(ii) exercício de direito de voto ou de influência relevante sobre as atividades da contraparte (tais como a submissão de decisões sobre preços, clientes, política comercial/vendas, planejamento, estratégias de marketing, interrupção de investimentos, descontinuação de produtos e outras);

(iii) recebimento de lucros ou outros pagamentos vinculados ao desempenho da contraparte;

(iv) desenvolvimento de estratégicas conjuntas de vendas ou marketing de produtos que configurem unificação da gestão;

(v) integração de força de vendas entre as partes;

(vi) licenciamento de uso de propriedade intelectual exclusiva à contraparte;

(vii) desenvolvimento conjunto de produtos;

(viii) indicação de membros em órgão de deliberação; e

(ix) interrupção de investimentos, etc.

21. As atividades descritas nas imagens referem-se, aparentemente, a testes e validações de procedimentos, o que pode não ser classificado como uma ingerência indevida de uma parte sobre a outra. Mesmo o papel que supostamente teria sido utilizado para confecção de carimbo é de impossível comprovação de autenticidade e origem, sendo facilmente replicável em qualquer editor de texto.

22. Embora as empresas tenham que manter suas atividades independentes, agindo como concorrentes, é natural que ocorram, durante o período de análise da operação, interações entre as equipes das duas instituições com o objetivo de preparar a integração das empresas em caso de uma aprovação. O próprio Guia sugere a formação de um parlor room, em que membros do comitê executivo de ambas as empresas poderão se reunir com o propósito de tratar do futuro processo de integração entre as empresas, em reuniões específicas para essa finalidade. 
23. A análise das imagens e de alguns termos nela utilizados indica que as orientações possuem objetivo de preparar as instituições para a futura integração, e não que estaria ocorrendo uma integração desde logo. São usados os termos "validação" para migração futura do parque de desktops e o termo "focais/focal", que denota que pessoas específicas de áreas distintas foram escolhidas para colaborar no processo de validação, o que não pode ser confundido com uma atuação conjunta das partes.

24. Nesse sentido, acompanho a SG no entendimento de que os indícios trazidos ao conhecimento do CADE não são suficientes para comprovar a consumação antecipada da operação. Isso não quer dizer, naturalmente, que se no futuro forem feitas outras denúncias em que sejam apresentadas provas mais robustas da consumação antecipada, as Requerentes estarão exoneradas de qualquer punibilidade. Caberá à SG analisar novamente o feito e sugerir encaminhamento a esse tribunal, como de praxe.

\section{III.2 Da Manutenção dos Empregos como Eficiência Global da Operação}

25. Em relação ao pleito referente à manutenção dos empregos, registro que, embora considere essa uma preocupação legítima do sindicato, principalmente na atual conjuntura econômica brasileira, tal pleito não configura uma preocupação concorrencial stricto sensu, não cabendo à autoridade antitruste rejeitar a presente operação única e exclusivamente em função dos efeitos no mercado de trabalho, nem mesmo exigir tal medida como condição necessária à aprovação da operação. A preservação de empregos, a meu ver, é um bem social que deve ser perseguido por políticas públicas específicas, e não pela autoridade de defesa da concorrência.

26. A manutenção de postos de trabalho tampouco se qualifica como uma espécie de possível eficiência da operação. Nem tudo que tem um efeito positivo é uma eficiência, e é preciso estressar bem esse ponto, pois muitas vezes essa pretensa acepção da palavra "eficiência" é utilizada no contexto antitruste para justificar decisões regulatórias, seja numa direção ou em outra. Eficiências são reduções de custos, otimizações do processo produtivo. Podem ser estáticas ou dinâmicas, mas não incluem, por exemplo, a geração de emprego ou a realização de um determinado valor de investimento que, por si só, não necessariamente gerará redução de custos passíveis de serem apropriados pelo consumidor final. 
27. Conforme bem sustentou agora há pouco o patrono do sindicato, é verdade que já houve casos em que o CADE admitiu compromissos de manutenção de empregos em acordos de controle de concentração. No entanto, a meu ver, tal compromisso tem que ser assumido unilateralmente pelas Requerentes no momento da proposição do ACC, e não partir de uma imposição do órgão antitruste em uma aprovação condicionada, ou de uma condição trazida pela autoridade para celebração do acordo. Até mesmo porque, tendo em vista que muitas vezes acordos são negociados entre as partes, a busca da preservação de postos de trabalho pode acabar prejudicando a negociação de uma solução para as preocupações verdadeiramente concorrenciais do ato de concentração.

28. Por essas razões, voto pela rejeição do pleito do sindicato.

\section{Da análise de mérito da operação pela superintendência- geral}

29. Após longa e detalhada análise do setor bancário brasileiro, a Superintendência-Geral (SG) emitiu o Parecer no 12/2016/CGAA2/SGA1/SG/CADE, de 01/04/2016 (SEI 0183982).

30. Em sua análise, para fins de definição de mercado relevante, a SG considerou dois cenários distintos: análise produto a produto e análise por clusters de produtos.

30. No primeiro cenário, a SG definiu vinte e cinco mercados relevantes: depósitos à vista; poupança e depósitos a prazo; antecipação de recebíveis; cobrança bancária; crédito de livre utilização - pessoa física; empréstimos consignados - pessoa física; financiamento habitacional - pessoa física; financiamento habitacional - pessoa jurídica; financiamento para a aquisição de veículos - pessoa física; crédito de livre utilização - pessoa jurídica; empréstimo em moeda estrangeira - pessoa jurídica; empréstimos direcionados a pessoa jurídica - financiamento rural; empréstimos direcionados a pessoa jurídica - repasses do BNDES; programas de fidelização individual; cartões de crédito; gestão de carteiras; administrador fiduciário de carteiras; grupo de seguro de pessoas; previdência privada; serviços de capitalização; corretagem de seguros; administração de consórcios para bens imóveis; administração de consórcios para veículos pesados; administração de consórcios para automotores, exceto motonetas e motocicletas; e arranjos de pagamento. 
31. Já no segundo cenário, a SG definiu os seguintes clusters: (i) depósitos à vista + depósito de poupança; (ii) depósito à vista + crédito de livre utilização; (iii) depósito à vista + depósito poupança + crédito de livre utilização; (iv) depósito à vista + depósito poupança + crédito de livre utilização + cartão de crédito; (v) depósito à vista + depósito poupança + crédito de livre utilização + cartão de crédito + seguro de pessoas; (vi) depósito à vista + crédito de livre utilização + cartão de crédito; (vii) depósito à vista + depósito poupança + cartão de crédito.

32. Na análise de possibilidade de exercício de poder de mercado, a SG fez uso dos dois cenários. Para os produtos individualmente considerados, foram realizadas análises de market share e de HHI, enquanto os testes de screening como UPP e GUPPI foram utilizados para as cestas. Volto a essa questão mais à frente neste voto.

33. Já a análise de probabilidade de exercício de poder de mercado foi feita apenas para o cenário agregado, e não para cada produto, uma vez que esta SG entendeu que os problemas concorrenciais encontrados se referem ao mercado bancário como um todo e a análise agregada contemplaria todas as variáveis de uma análise produto a produto.

34. As conclusões da SG foram de que a presente operação se insere em um mercado com evidências bastante claras de ausência de competição efetiva, com elevadas margens de lucro e baixa eficiência operacional, resultando em serviços mais caros e de menor qualidade para os consumidores, em um mercado com elevados custos de troca. A análise também deu conta de que se trata de um mercado com tendência de concentração e com elevadas barreiras à entrada. Ressaltou a Superintendência, ainda, outras características deletérias do setor bancário, como o baixo nível de satisfação do cliente, e a existência de um ambiente propício a comportamento coordenado entre os agentes, tais como alto nível de interação entre concorrentes, elevada concentração de mercado nas mãos de poucas instituições, fortes associações de classe, e a elevada simetria de participação entre os grandes bancos.

35. No entanto, tendo em vista que o percentual de market share representado pelo HSBC é relativamente baixo, e levando em consideração o que têm sido os precedentes do Conselho em análise de concentrações no setor bancário, a SG concluiu que o acréscimo de participação decorrente da operação, em termos de efeitos unilaterais ou coordenados, estaria aquém daquele capaz de gerar uma piora do quadro geral do setor. Dito de outra forma, a SG não encontrou nexo de causalidade entre a operação e os problemas concorrenciais identificados no setor bancário. 
36. Ainda assim, a Superintendência chamou atenção para o fato de que em um mercado com sérias preocupações concorrenciais, mesmo concentrações que a princípio podem ser consideradas pequenas devem ser avaliadas com grande cautela. Entendendo ser desproporcional alguma intervenção de natureza estrutural, optou então por negociar um acordo com medidas que pudessem garantir maior nível de bem-estar para os consumidores e tentar promover algum incremento de competição no mercado.

37. Assim, em 1ำ de abril de 2016, com fulcro no Parecer $n^{\underline{0}}$ 12/2016/ CGAA2/SGA1/SG/CADE, o Superintendente-Geral, por meio do Despacho SG nº 407/2016, ofereceu impugnação do presente ato de concentração a este Tribunal e recomendou sua aprovação condicionada à celebração do Acordo em Controle de Concentrações - ACC proposto pelas Requerentes, estruturados em quatro eixos principais: (i) Comunicação e Transparência, (ii) Treinamentos, (iii) Indicadores de qualidade e (iv) Compliance.

\section{Da instrução complementar no gabinete}

38. O presente ato de concentração foi distribuído à minha relatoria em 4 de abril de 2016, por ocasião da 110a Sessão Ordinária de Distribuição, portanto, 160 dias após à data da notificação. Em 8 de junho de 2016 (data da 87a Sessão Ordinária de Julgamento), perfazem 225 dias da notificação da operação ao CADE, dentro, portanto, do prazo de 240 previsto pela legislação para operações dessa complexidade.

39. De imediato, meu gabinete se aprofundou na análise das informações disponíveis nos autos e do Parecer no 12/2016/CGAA2/SGA1/SG/CADE, tendo concluído pela necessidade de instruções complementares que pudessem dar maior segurança sobre a conclusão da SG de que não haveria nexo causal entre a operação e a piora do ambiente concorrencial no setor bancário brasileiro. Nesse sentido, foram reavaliados: a definição do mercado relevante, os resultados dos testes quantitativos utilizados para filtragem de mercados com possibilidade de exercício de poder de mercado e a existência de potenciais eficiências da operação.

40. $\mathrm{O}$ resultado preliminar dessa análise foi exposto às Requerentes por meio do Despacho Decisório no 4/2016/GAB1/CADE (SEI 0200477), ${ }^{5}$ de

5 Até a sessão de julgamento o conteúdo do Despacho Decisório foi mantido de acesso restrito às partes no processo, nos termos do inciso XIV do art. 53 do RiCADE. A publicidade do 
16 de maio de 2016. Em que pese sua classificação como "Decisório" (devido à padronização de nomenclatura no sistema do CADE), o Despacho teve como objetivo levar a conhecimento das Requerentes as reflexões e estudos realizados no Gabinete de forma a permitir que fossem trazidos aos autos informações adicionais e contrapontos aos testes quantitativos realizados. Ato contínuo, portanto, as Requerentes protocolaram manifestações dialogando com o Despacho, cujos argumentos também foram discutidos em diversas reuniões realizadas no Gabinete. Abaixo, a relação das reuniões realizadas até 7 de junho de 2016 com as Requerentes.

Tabela 1

Reuniões com as Requerentes no Gabinete 1

\begin{tabular}{|c|c|}
\hline Data & $\begin{array}{c}\text { Lista de presença } \\
\text { (documento SEI) }\end{array}$ \\
\hline $14 / 04 / 2016$ & 188759 \\
\hline $28 / 04 / 2016$ & 193914 \\
\hline $05 / 05 / 2016$ & 196633 \\
\hline $13 / 05 / 2016$ & 200707 \\
\hline $19 / 05 / 2016$ & 202383 \\
\hline $20 / 05 / 2016$ & 203157 \\
\hline $24 / 05 / 2016$ & 203702 \\
\hline $30 / 05 / 2016$ & 205736 \\
\hline $31 / 05 / 2016$ & 205739 \\
\hline $02 / 06 / 2016$ & 206620 \\
\hline $07 / 06 / 2016$ & 208190 \\
\hline $07 / 06 / 2016$ & 208191 \\
\hline
\end{tabular}

41. Além disso, o Gabinete formalizou o Ofício nº 1949/2016/CADE, de 18 de abril de 2016, ao Departamento de Organização do Sistema Financeiro do Banco Central do Brasil (DEORF-BACEN), solicitando os documentos referentes à análise da operação realizada pelo órgão. A solicitação foi respondida em 25 de maio de 2016, por meio do Ofício no 10214/2016-BCB/ Deorf/Gabin. À resposta foi dado tratamento confidencial, conforme expressa requisição do $\mathrm{BACEN.}$

Despacho, com análises de cunho preliminar, poderia gerar expectativas no mercado e influenciar o valor de mercado das companhias envolvidas e até mesmo da operação, além de prejudicar a negociação do ACC. Com o julgamento e conclusões definitivas expostas no presente voto, uma versão pública do Despacho será disponibilizada nos autos públicos. 
42. Também foram realizadas audiências com o Instituto Brasileiro de Política e Direito do Consumidor - BRASILCON e com concorrentes das Requerentes, na busca de esclarecimentos adicionais que pudessem reduzir a assimetria de informação entre o regulador e o regulado na análise do caso.

43. Assim, as conclusões do presente voto levaram em consideração não só a instrução realizada na Superintendência-Geral, mas também os estudos complementares realizados após a distribuição do feito à minha relatoria e as interações com diversos agentes direta ou indiretamente afetados pela operação.

\section{Do mérito}

44. Desde que a presente operação foi declarada como complexa pela Superintendência-Geral, seus efeitos foram analisados sob duas perspectivas: uma que podemos chamar de "macro", relacionada ao contexto concorrencial do mercado no qual a operação está inserida, e uma segunda perspectiva "micro", focada na operação em si e no seu nexo de causalidade com eventuais problemas concorrenciais existente no setor bancário brasileiro. Opto por manter essa estratégia de análise, enfrentando primeiro a questão macro e, posteriormente, a questão micro.

\section{VI.1 Do Ambiente Concorrencial em que se Insere a Operação}

45. É fato inconteste que o mercado bancário brasileiro tem se tornado gradativamente mais concentrado durante as últimas duas décadas. Desde meados dos anos 1990,6 verificou-se uma "intensificação no processo de fusões e aquisições, tanto por instituições estrangeiras como por instituições nacionais, o que aumentou consideravelmente a concentração bancária". ${ }^{7}$ Nesse período, houve a privatização de vários bancos estaduais (Banespa,

6 O processo de concentração no setor bancário brasileiro teve início com programas governamentais de reestruturação do Sistema Financeiro Nacional como o PROER (Programa de Estímulo à Reestruturação e ao Fortalecimento do Sistema Financeiro Nacional) e o PROES (Programa de Incentivo à Redução do Setor Público Estadual na Atividade Bancária).

7 Camargo, Patrícia Olga (2009). A evolução recente do setor bancário no Brasil. São Paulo: Cultura Acadêmica, 2009. 
Banerj), a aquisição de bancos em dificuldades por instituições de maior porte, ${ }^{8}$ o aumento da participação de mercado dos bancos de origem estrangeira ${ }^{9}$, por último, a fusão entre grandes players do setor (Real + Santander, Itaú + Unibanco, etc.).

46. Essa concentração tem se dado, em geral, a partir dos grandes bancos comprando os menores. Isso pode ser visto na ilustração constante do Parecer Técnico no 12/2016/CGAA02/SGA1/SG/CADE, a qual reproduzo abaixo:

Figura 1

Principais Fusões no Setor Bancário

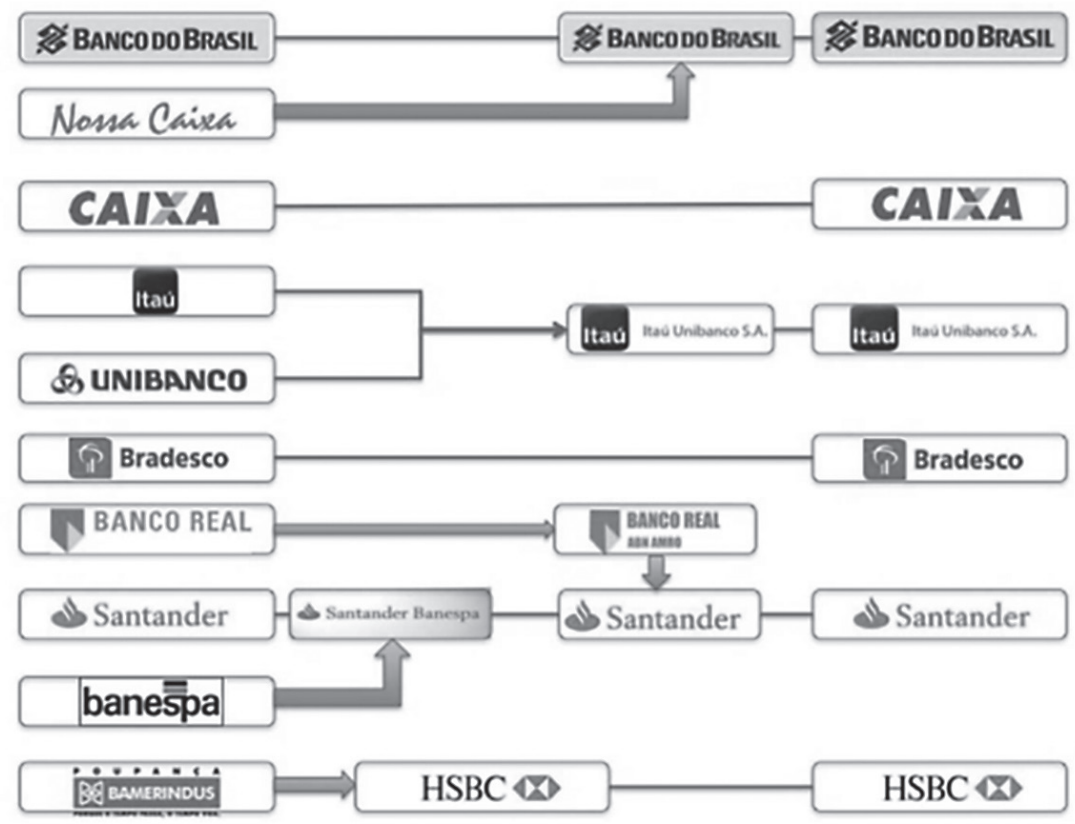

Fonte: Superintendência-Geral.

8 Como exemplo, o Banco Econômico foi incorporado pelo Banco Excel, que passou a se chamar Banco Excel-Econômico. Posteriormente, em agosto de 1998, o conjunto foi incorporado pelo Banco Bilbao Vizcaya Argentaria e, em 2003, ao Bradesco.

9 Em 2007, o Grupo Santander adquiriu o ABN Amro, que já havia adquirido o Banco Real em 1998. 
47. O processo também pode ser quantificado a partir das informações sobre a evolução da participação de mercado dos grandes bancos (BB, CEF, Itaú, Bradesco e Santander) nos últimos dez anos, por critérios como ativos totais e volume total de depósitos. Se em 2005, os outros bancos eram responsáveis por quase $40 \%$ de mercado, considerando ativos totais, em 2014, esses bancos passaram a deter apenas $77,49 \%$. O gráfico abaixo ilustra esse movimento:

Gráfico 1

Participação em Depósitos (5 maiores bancos)

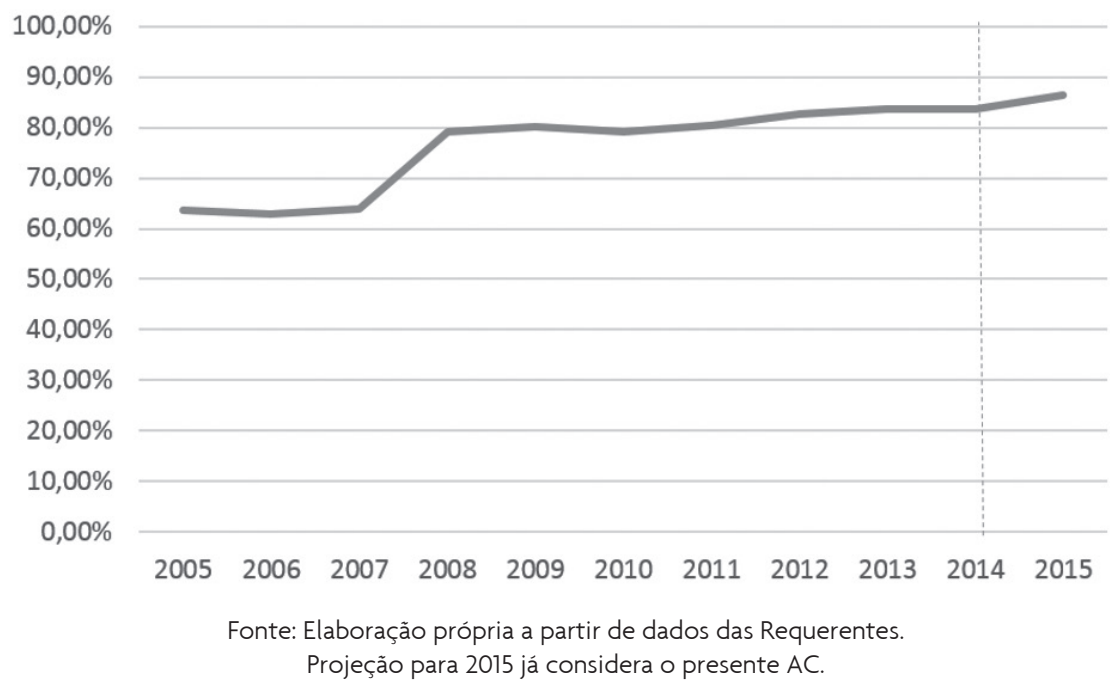

48. Além do contínuo e preocupante grau de concentração que o setor vem adquirindo, a partir de evidências e referências a estudos específicos, a Superintendência-Geral destacou, conforme dito acima, algumas características incômodas do setor bancário brasileiro, principalmente em face dos setores bancários de outros países. Mais especificamente, caracterizou o setor no Brasil como sendo:

1. um dos mais concentrados do mundo; ;0

2. de elevados níveis de lucratividade;

10 Editorial de 23/1/2016: Terra de Gigantes. http://m.folha.uol.com.br/opiniao/2016/01/1732720terra-degigantes.shtml (acessado em 10/2/2016). http://www1.folha.uol.com.br/mercado/2016/ 01/1730946-bancos-medios-vao-acabar-ate-2025-preveconsultoria.shtml. 


\section{3. de baixa eficiência; ${ }^{11}$}

4. de baixo nível de competitividade. ${ }^{12}$

49. Tal avaliação do setor bancário brasileiro delineada pela Superintendência-Geral foi contestada pelas Requerentes por meio do estudo "Considerações ao Despacho do Conselheiro-Relator", de elaboração da LCA Consultores (SEI 203119), em que defende que "o grau de concentração do mercado bancário brasileiro bem como a margem dos bancos não difere expressivamente numa comparação internacional" e que "vários indicadores de eficiência e competição mostram melhora no quadro competitivo do setor bancário brasileiro no período recente".

50. Para formar opinião própria, analisamos com maior ou menor ímpeto cada um dos pontos de divergência entre a SG e as Requerentes, cujo breve relato é feito a seguir, ponto a ponto.

\section{VI.1.1 Grau de Concentração do Setor Bancário}

51. Como dito acima, não me parece restar dúvida de que o setor bancário nacional vem elevando significativamente seus níveis de concentrações nas décadas recentes e que possui, de um modo geral, um elevado grau de concentração. A questão a se discutir aqui é se esse nível ainda é saudável do

11 Segundo dados da consultoria econômica Economática, a rentabilidade mediana dos bancos com ação na bolsa em 2013 foi de 12\%. Se considerarmos apenas a rentabilidade dos maiores bancos, que concentram cerca de $80 \%$ do mercado, a rentabilidade chega a $20 \%$. Outros setores da economia apresentaram rentabilidade bem inferior ao setor financeiro: Setor de Construção $(10,7 \%)$, Energia Elétrica $(9,8 \%)$, Têxtil $(6,6 \%)$, Alimentos e Bebidas $(5,8 \%)$, Siderurgia e Metalurgia (5,6\%), Setor Químico (5,09\%) e Telecomunicações (-1,42\%).

"Após analisar o balanço e as declarações de renda para os maiores bancos do país, Nunes, Menezes e Dias (2013) concluíram que os bancos brasileiros são rentáveis, mas menos eficientes do que bancos em outros países da América Latina, Estados Unidos, Japão e países da zona do euro. Os autores também afirmaram que os dados indicam que os bancos atuam como um oligopólio e que práticas não competitivas podem explicar os preços excessivos e restrição de oferta para os clientes. Esses resultados são corroborados por relatório do Bank for International Settlements (BIS) que indica que os bancos brasileiros são os mais lucrativos do mundo, mas também estão entre os mais ineficientes. Segundo o relatório, entre os anos de 2000 e 2007, os bancos brasileiros foram os segundos mais rentáveis do mundo, perdendo apenas para as instituições da Rússia. Já entre 2008 e 2011, os bancos nacionais lideraram o ranking de lucratividade. Entre 2013 e 2014, os bancos brasileiros figuraram em terceiro lugar no mundo, atrás de Rússia e China. Por outro lado, o relatório demonstra também que as instituições nacionais são as mais ineficientes do mundo dentre as principais economias, com elevados custos administrativos." Parecer Técnico 12/2016/CGAA02/SGA1/SG/CADE (Parágrafos 319/320).

12 Parecer Técnico 12/2016/CGAA02/SGA1/SG/CADE (Parágrafos 322). 
ponto de vista concorrencial. Uma forma de fazê-lo é através de comparações internacionais, como propuseram as Requerentes.

52. Nesse ponto, houve uma divergência entre os resultados apresentados no estudo realizado pela Consultoria Roland Berger e no parecer produzido pelo Professor Márcio Nakane a pedido das Requerentes, denominado "Avaliação do Quadro Competitivo no Setor Bancário Brasileiro", acostado aos autos por meio da petição SEI 0198892. A diferença principal é quanto aos níveis de concentração em países europeus. Este Gabinete analisou a fundo a divergência e concluiu que essa decorre da utilização de dados distintos para subsidiar as análises realizadas: o parecer do prof. Nakane se baseia em dados disponibilizados pelo Banco Mundial a partir de números produzidos pela consultoria Bureau Van Djik e conhecido como Bankscope, enquanto o estudo da Roland Berger utiliza parcialmente os dados da Bankscope e parcialmente os dados do Structural Indicators for the EU Banking Sector Online, produzidos pelo Banco Central Europeu..$^{13}$ Nesse segundo banco de dados, os valores de concentração do setor bancário europeu são expressivamente inferiores aos apontados no Bankscope, o que nos parece decorrer de diferenças metodológicas na definição dos mercados relevantes pelas duas instituições. ${ }^{14}$ Os números informados para o Brasil no Bankscope são diferentes dos números apresentados pelas Requerentes no processo, por exemplo, corroborando essa hipótese.

53. Em função das limitações de prazo e de recursos humanos, não conseguimos aprofundar ainda mais no esclarecimento dessas divergências metodológicas. Em geral, preferimos trabalhar com dados públicos (ou produzidos por entidades públicas oficiais), e nesse sentido daríamos mais peso aos números do Banco Central Europeu, mas, por outro lado, uma comparação robusta requer que seja mantida a mesma metodologia para os diferentes países, e nesse sentido os dados do Bankscope usados pelas Requerentes seriam mais razoáveis. Em virtude dessas considerações, entendo que devamos agir com cautela e qualificar bem qualquer conclusão.

54. Além da questão da origem e do tratamento metodológico dos dados, também defendo que qualquer comparação deve ser feita primordialmente com países com caraterísticas semelhantes às do Brasil, e não com todo o resto

13 Disponível em: https://sdw.ecb.europa.eu/browse.do?node=9484387.

14 Por exemplo, a inclusão ou não de associações e cooperativas bancárias, bancos de investimentos etc. e não apenas bancos comerciais. 
do mundo. Na análise apresentada pelas Requerentes, os números do setor bancário brasileiro foram ranqueados e comparados com a média mundial, com a média da Zona do Euro, com a média dos países ricos e com os vizinhos sul-americanos. No estudo da Roland Berger, a comparação é focada em países europeus.

55. O mais adequado, a meu ver, seria verificar a concentração brasileira frente a países de dimensões geográficas e populacionais semelhantes às brasileiras, pois essas características me parecem ser relevantes para definir a estrutura de muitos mercados, dentre eles o bancário. Uma forma de fazer isso foi selecionar para comparação a lista de países que constam da interseção do conjunto dos 30 maiores países do mundo, em extensão territorial, com o conjunto dos 30 países de maior população mundial ${ }^{15}$ (ou seja, países grandes com grandes populações). A lista inclui os BRICS, grandes países latinoamericanos (México e Colômbia), e alguns países desenvolvidos. O resultado é apresentado na tabela abaixo:

Tabela 2

Concentração Bancária em Países Selecionados (C5)

\begin{tabular}{|l|r|}
\hline PAÍS & \% C5 \\
\hline ÁFRICA DO SUL & 99,4 \\
\hline COLÔMBIA & 87,1 \\
\hline BRASIL & 76,5 \\
\hline CONGO & 75,4 \\
\hline MÉXICO & 67,5 \\
\hline ESTADOS UNIDOS & 47,4 \\
\hline CHINA & 45,9 \\
\hline INDONÉSIA & 42,5 \\
\hline ÍNDIA & 38,4 \\
\hline RÚSSIA & 11,9 \\
\hline
\end{tabular}

Fonte: Bankscope (2013) e The World Factbook. Elaboração própria.

56. Como vemos, o Brasil aparece em 3 o lugar. Chamo atenção para o fato de que o número que consta na base para o Brasil, como dito anteriormente, é

15 A fonte das informações foi o "The World Factbook", uma publicação anual da CIA (Central Intelligence Agency) dos Estados Unidos da América. 
inferior ao informado pelas Requerentes nos autos, e ainda não contempla o resultado da aquisição do HSBC pelo Bradesco. ${ }^{16}$

57. Utilizando outro critério de seleção de países, qual seja, aquele adotado pelo BIS na publicação de seu relatório anual com dados de 15 países selecionados (provavelmente referente aos principais sistemas financeiros do mundo), corroboramos o protagonismo do mercado brasileiro quando o assunto é grau de concentração:

Tabela 3

Concentração Bancária em Países Selecionados pelo BIS (C5)

\begin{tabular}{|lr|}
\hline PAÍS & C5 (\%) \\
\hline Japão & 97,6 \\
\hline Espanha & 97,5 \\
\hline Canadá & 83,6 \\
\hline Brasil & 76,5 \\
\hline Alemanha & 68,7 \\
\hline Reino Unido & 64,1 \\
\hline Suíça & 61,2 \\
\hline Suécia & 60,8 \\
\hline Estados Unidos & 47,4 \\
\hline China & 45,9 \\
\hline França & 43,3 \\
\hline Índia & 38,4 \\
\hline Itália & 36,7 \\
\hline Rússia & 11,9 \\
\hline
\end{tabular}

Fonte: Bankscope (2013). Elaboração própria.

58. Uma segunda forma de olhar a questão é dar um tratamento levemente mais consistente do ponto de vista estatístico, cruzando os dados de concentração com dados de extensão territorial para a base dos 30 maiores países para os quais há dados (21 no total) de concentração para o ano de 2013 no Bankscope; podemos observar que o Brasil (em destaque no gráfico abaixo), juntamente com o Canadá, figura como outlier do grupo:

16 Com base nos números das Requerentes, a SG calculou, no parágrafo 35 de seu Parecer, em $86,86 \%$ a concentração dos seis maiores bancos no Brasil em depósitos totais, o que equivaleria à inclusão do HSBC como parte do Bradesco. 
Gráfico 2

Relação Concentração (C5) x Extensão Territorial em Países Selecionados

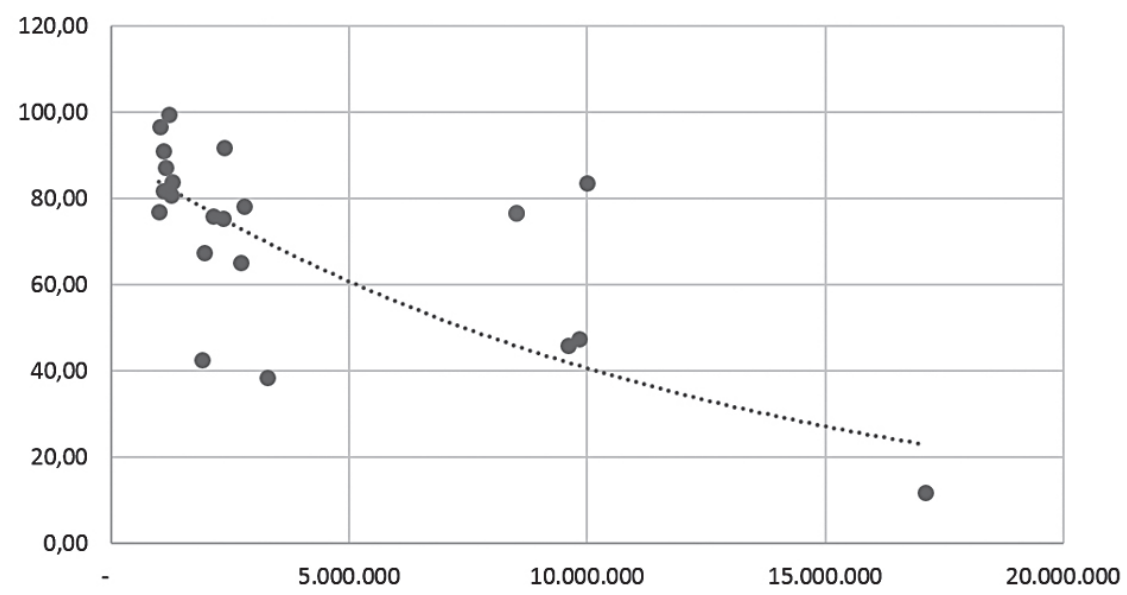

Fonte: Bankscope (2013) e The World Factbook. Elaboração própria.

59. Com base nesses dois exercícios, tendo a pender para o posicionamento firmado pela SG, no sentido de que, ante países comparáveis, o Brasil é um outlier e se encontra no topo do ranking de concentração bancária, mesmo utilizando para comparação a base de dados Bankscope que, inicialmente, sinalizava no sentido de corroborar as alegações das Requerentes.

\section{VI.1.2 Lucratividade do Setor Bancário}

60. A SG havia apontado em seu parecer, citando o Banco Mundial, que " $o$ spread bancário brasileiro é um dos mais altos do mundo" e que "em 2015, o país ficou na terceira posição no ranking mundial de spread, no qual foram avaliados 114 países". As Requerentes contestaram esse ponto, alegando que os dados de spread da base citada pela SG têm peculiaridades que não permitem uma comparação direta, pois, para o caso brasileiro, trata-se do spread para operação com taxas de juros prefixadas e para todos os segmentos de tomadores, enquanto outros países informam taxas de juros médias entre operações pré e pós-fixadas, sendo que alguns informam dados para tomadores "prime", segmento de menor risco e, portanto, menor spread. Além disso, alegam que spread elevado não é necessariamente sinônimo de alta lucratividade. 
61. Quanto ao primeiro argumento, de incompatibilidade, rejeito-o por entender que todos os números de bases de dados internacional padecem dessas dificuldades, inclusive os de concentração bancária usados pelas próprias Requerentes para tentar demonstrar que o setor brasileiro não está se tornando muito concentrado. Com base no argumento de que as metodologias de cada país não são exatamente as mesmas, poderíamos descartar qualquer uso desses dados para comparações internacionais, e isso, me parece, empobreceria a análise.

62. Por outro lado, aceito o argumento das Requerentes de que spread bancário não é uma boa proxy para lucratividade, por duas razões: em primeiro lugar, porque o tamanho do spread tem que ser ajustado como proporção do custo total dos bancos, como custo de captação e risco do negócio, e isso não foi feito na comparação trazida pela SG; em segundo lugar, porque fatores macroeconômicos, como políticas de orientação de crédito, por exemplo, geram subsídios cruzados e tendem a influenciar fortemente o valor do spread. Não podemos descartar essa hipótese para o caso brasileiro, ainda que tampouco confirmá-la, por isso optamos por não usar números de spread para avaliar lucratividade.

63. Não obstante, o estudo de Reis Júnior (2015), ${ }^{17}$ utilizando dados de spread bancário ex post, identificou uma relação positiva entre a participação de mercado do banco, em termos de ativos, e o spread bancário ex post. Muito embora esse estudo tenha identificado que a concentração do mercado como um todo não seria relevante para determinar o nível do spread ex post, suas conclusões apontam no sentido de que um aumento da competição no setor bancário seria benéfico, na medida em que menores participações de mercado de um determinado banco tendem a reduzir o nível de spread.

64. Em contraposição ao uso do spread bancário como proxy para a lucratividade, as Requerentes apresentaram, novamente, dados do Bankscope demonstrando que o indicador ROE (return on equity), que mede o lucro líquido dos bancos sobre seu patrimônio líquido, revelaria que a lucratividade do setor bancário tem caído nos últimos anos e não está descolada da média mundial. Primeiramente, acreditamos que olhar apenas para o último ano da série pode ser enganoso, pois enquanto em 2013 a maioria dos países saía da crise financeira internacional iniciada em 2008, o Brasil, talvez em

17 Reis Junior, H. Ensaios sobre economia bancária: uma análise da competição, concentração, eficiência e spread do setor bancário brasileiro no período recente. 2015. $415 \mathrm{f}$. Tese (Doutorado em Economia) - Instituto de Economia, Universidade Federal do Rio de Janeiro, Rio de Janeiro. 
função de políticas anticíclicas, que passaram a dar os primeiros sinais de esgotamento naquele ano, tenha começado a registrar os primeiros resultados menores que a média histórica. Na média dos últimos 5 anos, por exemplo, o Brasil assume uma posição muito mais próxima ao topo do ranking nesse indicador, situando-se acima da média mundial. ${ }^{18}$

65. Conforme bem apontado pela SG, o Bank for International Settlements - BIS parece compartilhar desse entendimento. Usando números de margem líquida de lucro, também disponibilizado pela base do Bankscope, o 85ํㅜ Relatório Anual do "banco dos bancos" traz uma tabela com a rentabilidade de grandes bancos em países selecionados segundo seu próprio critério. A tabela é reproduzida abaixo. Como se pode ver, os bancos brasileiros, para esses países selecionados pelo BIS, aparecem como os de maior rentabilidade no período de 2009 a 2014.

Tabela 4

Rentabilidade dos Principais Bancos em Países Selecionados

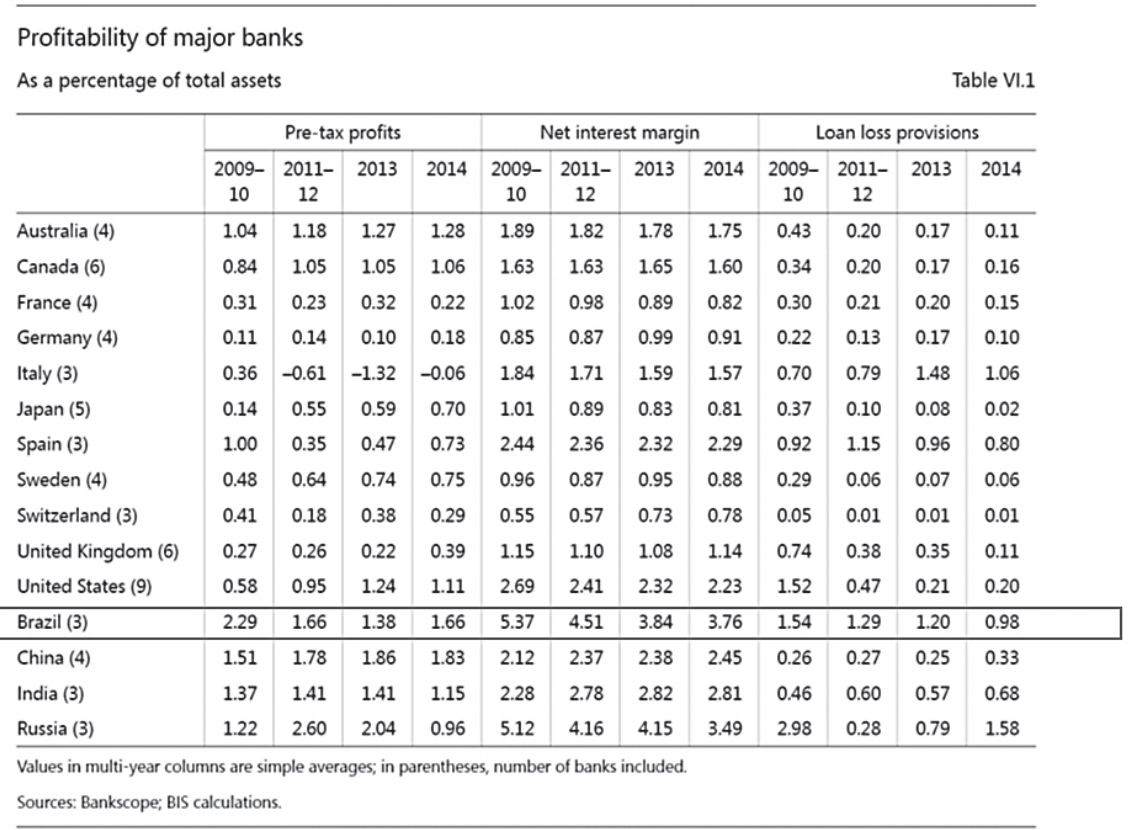

18 Conforme dados do Bankscope. 
66. Além disso, importante lembrar que cerca de metade do setor bancário brasileiro é composto por bancos públicos, que em diversos mercados não buscam necessariamente a maximização de lucros, mas a consecução de políticas públicas. Isso tende a imprimir um viés de subestimação da lucratividade dos bancos no Brasil, mas que não fomos capazes de verificar quantitativamente.

\section{VI.1.3 Ineficiência no Setor Bancário}

67. Outro ponto de discordância entre a SG e as Requerentes foi quanto à suposta ineficiência do setor bancário brasileiro. O mesmo estudo do BIS é citado pela Superintendência como referência para a ineficiência do setor bancário brasileiro. Não encontramos essa referência no estudo ao qual tivemos acesso, muito provavelmente em virtude de se tratarem de edições distintas.

68. Porém, para além dos pontos levantados pela SG, realizamos consulta à mesma base de dados do Bankscope, que traz 10 indicadores de ineficiência de setores bancários ao redor do mundo. Devido à limitação temporal, analisamos apenas seis desses dez indicadores: Proporção dos Custos sobre as Receitas dos Bancos (\%), Margem Líquida de Lucro dos Bancos (\%), Retorno dos Bancos sobre os Ativos (\% após impostos), Retorno dos Bancos sobre o Capital Próprio (\% após impostos), Despesas Gerais dos Bancos sobre os Ativos Totais (\%) e Número de Agências por 100 mil Habitantes.

69. Em apenas três deles, ou seja, a metade, o Brasil destoa dos demais países, posicionando-se no primeiro quartil do ranking de menos eficiente para mais eficiente, principalmente no relacionado ao número de agências por habitantes. ${ }^{19}$ Em função disso, não encontramos evidências suficientes para afirmar que o setor bancário brasileiro é nitidamente menos eficiente que a média dos bancos de outros países do mundo.

19 Os outros dois indicadores para os quais o Brasil se destaca em termos de ineficiência são Retorno sobre os Ativos e Retorno sobre o Capital Próprio. 


\section{VI.1.4 Concorrência no Setor Bancário}

70. Quanto à concorrência no setor bancário, a SG faz referência a estudo da Competition and Markets Authority - CMA, autoridade antitruste do Reino Unido, que relaciona qualidade do serviço prestado com concorrência. Reproduzo abaixo esse trecho do parecer da Superintendência:

323. O estudo do CMA relatou que, mais até do que o preço, o fator qualidade de serviço é importante para analisar o nível da concorrência no mercado bancário, sobretudo em razão das dificuldades percebidas pelo consumidor em avaliar o fator preço neste mercado, devido à presença de assimetrias de informação. Em um mercado competitivo, as empresas se esforçam para ofertar produtos com maior qualidade, de forma a conquistar e manter clientes. Como mencionado pela Comissão Europeia, a concorrência "incentiva as empresas a melhorar a qualidade dos bens e serviços que vendem a fim de atrair mais clientes" e, assim, obter uma fatia maior do mercado. De fato, mais do que angariar novos clientes, o nível de qualidade dos produtos e serviços ofertados é uma questão estratégica para manter clientes. Se o preço é importante para a primeira compra, a qualidade é fundamental para que os consumidores voltem a consumir o produto.

324. Dessa forma, seria instintivo supor que empresas líderes de mercado ofertassem os produtos de maior qualidade. Caso contrário, elas não conseguiriam manter participação elevada, uma vez que seus clientes buscariam produtos melhores em outros fornecedores. No caso do mercado bancário inglês, entretanto, o resultado encontrado foi distinto, demonstrando falta de competitividade no setor. O estudo observou que os bancos com uma pontuação maior no quesito satisfação dos consumidores eram os que detinham menor participação de mercado. Por outro lado, os bancos com menores índices de satisfação dos consumidores eram aqueles com os maiores shares de mercado. Como argumentado pelo CMA, esse não é comportamento esperado em um mercado competitivo. Em um mercado de livre concorrência, o mais racional seria que empresas com baixos níveis de qualidade perdessem market shares para empresas com níveis maiores de qualidade. Em casos em que isso não acontece, há indícios de que o mercado não é competitivo e de que as empresas estão se mantendo em posições elevadas não por serem mais eficientes, mas por estarem exercendo seu poder de mercado. 
71. Com base nesse raciocínio, a Superintendência traz aos autos números que expressam a satisfação dos clientes com a prestação de serviços bancários, com destaque para um gráfico de um estudo que compara esse indicador com os de outros países, conforme trecho a seguir:

325. Em uma análise comparativa o mercado brasileiro apresenta situação semelhante ao britânico. Segundo o Sistema Nacional de Informações de Defesa do Consumidor - SINDEC, os assuntos "banco comercial" e "cartões de crédito" ficaram em segundo lugar na lista de reclamações dos Procons em 2015, perdendo apenas para telefonia celular. De acordo com o boletim do SINDEC de 2015, os bancos comerciais estão entre os setores que mais levam consumidores aos Procons, no Brasil.

326. O Índice Brasileiro de Satisfação de Clientes avalia a qualidade dos produtos e serviços disponíveis no mercado brasileiro, com base na satisfação de clientes. Em apresentação feita em abril de 2015, o BSCI mostrou que o índice de satisfação de clientes com bancos de varejo no Brasil é menor do que em outros países, como demonstra o gráfico abaixo.

\section{Gráfico 3}

Índice de satisfação de clientes com bancos de varejo por país

\section{Comparação Internacional}

\section{Bancos de Varejo}

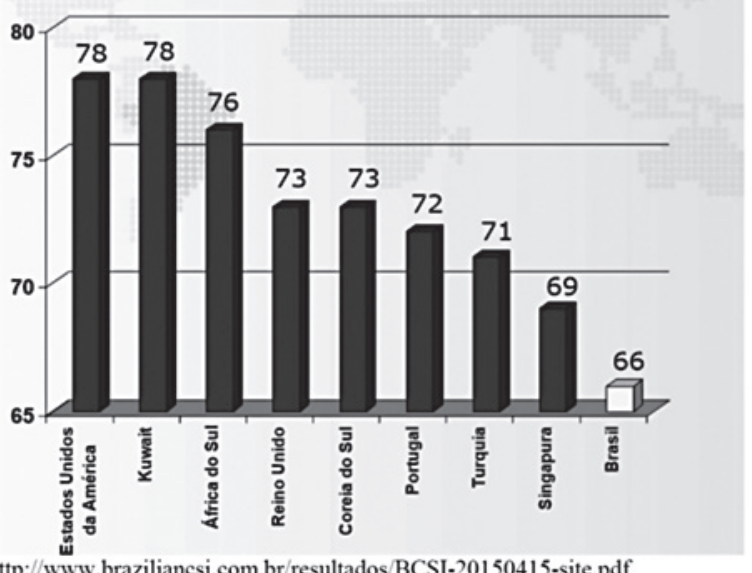

Fonte: http://www.braziliancsi.com.br/resultados/BCSI-20150415-site.pdf 
72. Além de apontar para indícios que relacionam baixa qualidade com baixa concorrência, a SG destaca que a forte assimetria de informação e os altos custos de transação observados pelos consumidores nesse mercado criam um efeito denominado no setor de "lock in", fazendo com que os clientes de instituições bancárias, em geral, tenham pouco ou nenhum incentivo para pesquisar os melhores preços e a qualidade de outras instituições e, eventualmente, mudar de banco. Os fatores que reforçam essa dificuldade, extraídos do voto do Conselheiro César Mattos no voto do AC no 08012.011736/2008-4120 e complementados por reflexões da própria Superintendência-Geral, seriam:

1. Dificuldade de fechamento de conta corrente no banco de origem (devido a débitos automáticos, pagamento de salário etc.);

2. Procedimentos burocráticos necessários à troca;

3. Cancelamento de cartões antigos, muitos com financiamento de compras a prazo;

4. Memorização de novas senhas;

5. Política de precificação dos bancos via subsídio cruzado (descontos de anuidades e tarifas para clientes com contratos de seguros, financiamento etc.);

6. Importância do histórico do cliente para que as instituições bancárias concorrentes possam precificar certos produtos, principalmente os que envolvem riscos;

7. Benefícios oriundos de sistemas de fidelização criados pelos bancos, que concedem descontos segundo o prazo de relação do cliente com o banco.

73. Todos esses elementos fazem com que os clientes fiquem "presos" às instituições financeiras, migrando apenas em casos extremos, como por solicitação de um novo empregador. Como exemplo disso, o instituto da portabilidade, mesmo após concentrado esforço do Banco Central na regulamentação e promoção, praticamente não é utilizado pelos clientes dos bancos, conforme indicam as tabelas constantes do item 344 do referido Parecer da SG.

74. Em resposta às preocupações quanto ao nível de concorrência no setor, as Requerentes apresentaram os resultados da aplicação de testes com três indicadores usualmente utilizados para captar rivalidade em uma atividade

20 Requerentes Banco do Brasil S.A. e Banco Nossa Caixa. 
econômica, também extraídos da base Bankscope: Índice de Boone, Índice H de Panzar-Roose e Índice de Lerner. ${ }^{21}$ Dos três indicadores, o primeiro vem sinalizando a redução do grau de concorrência, o segundo um aumento do grau de concorrência e o terceiro, o índice de Lerner, varia fortemente a cada ano, indicando a não correlação com o crescente grau de concentração observado nos últimos anos. Em virtude disso, do fato de o Índice de Lerner também poder ser um indicativo de ineficiência no setor (ou seja, um valor baixo pode indicar não necessariamente ausência de poder de mercado, mas também altos custos) e pelo fato de o mesmo índice calculado a partir de dados primários do Banco Central apresentar resultados diferentes e bem menos voláteis que aquele reportado na base do Bankscope, opto por desconsiderá-lo.

75. Em relação aos demais índices, conforme dito, há divergência na sinalização da direção que vem tomando o grau de concentração no Brasil. Em função disso, tendo a confiar mais nos resultados do Índice de Boone, que mede a elasticidade dos lucros a variações dos custos marginais, pois a variação do Índice $\mathrm{H}$, sensível ao crescimento das receitas dos agentes, pode estar contaminada por fatores que pressionam a demanda, principalmente considerando que em anos recentes houve uma forte inserção de segmentos de menor poder aquisitivo no mercado bancário brasileiro em virtude da evolução do nível de renda no país, e não tivemos acesso à forma como o índice foi calculado para nos certificarmos de que foram inseridos nas equações os devidos controles para essa variável. Assim, acompanhando a sugestão da literatura de analisar os três indicadores conjuntamente, ${ }^{22}$ entendo

${ }^{21}$ Índice de Boone: Mensura o grau de competição dada pela elasticidade dos lucros com relação ao custo marginal. Para obter a elasticidade, regride-se o logaritmo dos lucros contra o logaritmo dos custos marginais. A racionalidade por detrás desse indicador é que os lucros mais elevados são alcançados pelas instituições mais eficientes. Então, quanto mais negativo o indicador, maior o grau de competição porque o efeito da realocação é mais forte.

Índice H (Panzar-Roose): Mede o grau de competição na indústria bancária pela elasticidade da receita dos bancos com relação ao preço dos insumos. Em concorrência perfeita, um aumento no preço dos insumos eleva o custo marginal e a receita total na mesma proporção, sendo então o resultado do teste igual a 1. Em monopólio, um aumento no preço dos insumos eleva o custo marginal, reduz o nível de produção e reduz a receita total, fazendo com que o resultado do teste seja negativo ou nulo. Quando o resultado está entre zero e 1, o mercado opera sob concorrência monopolística.

Índice de Lerner: Dado pela diferença entre o preço final e o custo marginal (relativo aos preços). Os preços são calculados pelo total das receitas bancárias sobre os ativos, enquanto o custo marginal é obtido a partir da estimação da função de custos com relação à produção. Quanto mais elevado o Índice de Lerner, menor a competição bancária.

22 LEON, F. Measuring Competition in Banking: A critical review of methods. Etudes et Documents no 12. CERDI. 2014. Acessado em http://cerdi.org/uploads/ed/2014/2014.12.pdf em 12 de maio de 2016. 
que a melhor compreensão do fenômeno é a de que tem havido, se não uma redução, pelo menos uma estagnação do grau de concorrência no setor nos últimos anos.

76. Além desse ponto trazido pelas Requerentes, consta no [ACESSO RESTRITO AO CADE].

77. Além disso, é importante controlar também para variações de market shares de certos agentes em função dos resultados de políticas públicas. Em particular, suspeitamos que a trajetória da participação da Caixa Econômica Federal em certos mercados possa ser mais em decorrência de o banco ser um importante braço do governo federal de implantação e execução de políticas públicas do que de um crescimento "natural", uma vez que esse seu papel foi intensamente reforçado nos últimos governos.

78. Para concluir a análise de concorrência e rivalidade no setor, trago ainda o quantitativo de investigações de condutas anticoncorrenciais envolvendo instituições do sistema financeiro nacional atualmente sob investigação da Superintendência-Geral, o que reforça minha convicção no sentido de que a rivalidade no setor é sim motivo de preocupação para a autoridade antitruste:

Tabela 5

Investigações de Condutas Envolvendo Instituições Financeiras

\begin{tabular}{|c|c|}
\hline Quantidades & Tipos de Condutas \\
\hline 3 & Inquérito Administrativo \\
\hline 3 & Procedimentos Preparatórios \\
\hline 7 & Processos Administrativos \\
\hline
\end{tabular}

Fonte: Superintendência-Geral. Atualizado até maio 2016.

79. Feitas todas essas considerações sobre o mercado bancário brasileiro como um todo, afirmo minha convicção de que as evidências apontam predominantemente no sentido de que há grandes riscos concorrenciais no setor, compartilhando, em geral, das preocupações levantadas pela Superintendência-Geral.

80. Passo agora à análise específica da operação, nos termos da tradição dos guias de análise antitruste vigentes no Brasil e nas principais jurisdições internacionais. 


\section{VI.2 Do Mercado Relevante}

81. A delimitação do mercado relevante para serviços e produtos bancários não constitui tarefa trivial, quer seja com relação à dimensão produto ou à dimensão geográfica. Observamos diversas características nesse setor que o tornam peculiar, quais sejam, a presença de economias de escala e de escopo, assimetria de informação, grande diversidade e interdependência dos produtos oferecidos, etc. A dificuldade com essa etapa da análise é corroborada, ainda, pelo histórico de como o mercado relevante tem sido definido pelo Conselho ao longo do tempo, que vem variando a cada operação, conforme bem resumiu o parecer da SG.

\section{VI.2.1 Dimensão Produto}

82. Na dimensão produto, a discussão empreendida em decisões precedentes deste Conselho ${ }^{23}$ consiste em ponderar se faz sentido agrupar os produtos bancários em cestas ("clusters") para fins de análise antitruste ou se seria mais adequado considerar cada produto ou serviço como um mercado relevante distinto, agrupando apenas aqueles que podem ser considerados como substitutos próximos.

83. A Superintendência-Geral elaborou um quadro-resumo ${ }^{24}$ dos principais argumentos apresentados contra e a favor da análise por cluster no mercado bancário, pela doutrina e pela jurisprudência internacional e nacional, como podemos ver a seguir:

23 No Ato de Concentração no 08012.010081/2007-11 (Banco Santander Hispano S/A e ABN Amro), julgado em 2007, o Conselheiro Abrahan Benzaquen Sicsú defendeu o uso do cluster de produtos financeiros para a análise do setor bancário. O Conselheiro César Costa Alves de Mattos, ao analisar o Ato de Concentração no 08012011736/2008-41 (Banco do Brasil S.A. e Banco Nossa Caixa S.A.), separou os produtos financeiros em dois mercados relevantes: operações de crédito e depósitos bancários. No Ato de Concentração no 08012.011303/2008-96 (Banco Itaú S.A. e Unibanco). Em seu voto, o Conselheiro Relator Fernando de Magalhães Furlan argumentou que o mercado bancário não atenderia a dois critérios essenciais para a utilização da análise por cluster, quais sejam: a existência de custos de transação significativos em lidar com mais de um banco e os custos de desagregar os produtos serem grandes em relação ao custo da cesta de produtos.

24 Anexo ao Parecer Técnico no 12/2016/CGAA02/SGA1/SG/CADE (SEI 0183985). 
Quadro 5

Argumentos a Favor e Contra a Análise do Setor Bancário por Cluster

\begin{tabular}{|c|c|}
\hline Argumentos a favor do clustering & Argumentos contra o clustering \\
\hline \multicolumn{2}{|c|}{ Internacional } \\
\hline $\begin{array}{l}\text { A atuação das instituições bancárias é única e } \\
\text { inclui produtos que apenas elas podem ofertar. } \\
\text { Dessa forma, os bancos concorrem apenas com } \\
\text { outros bancos. }{ }^{25}\end{array}$ & $\begin{array}{l}\text { Instituições especializadas que ofertem certos serviços } \\
\text { de interesse do consumidor podem ser erroneamente } \\
\text { excluídas de um cluster se não ofertar todos os pro- } \\
\text { dutos da cesta. }{ }^{26}\end{array}$ \\
\hline $\begin{array}{l}\text { Simplificação da análise, evitando uma investiga- } \\
\text { ção econômica ampla nos vários submercados } \\
\text { que compõem o cluster. }{ }^{27}\end{array}$ & $\begin{array}{l}\text { A análise por cluster tende a subestimar a competição } \\
\text { no mercado ao ignorar o papel de instituições } \\
\text { especializadas na oferta de um ou alguns produtos. }{ }^{28} \\
\end{array}$ \\
\hline $\begin{array}{l}\text { Alguns produtos e serviços bancários são tão } \\
\text { distintos que não enfrentam competição efetiva } \\
\text { dos produtos e serviços de outras instituições } \\
\text { financeiras. }{ }^{29}\end{array}$ & $\begin{array}{l}\text { A análise por cluster pode superestimar a competição } \\
\text { no mercado ao erroneamente inferir, a partir da } \\
\text { existência de competição abundante para a oferta de } \\
\text { um dos produtos da cesta, que também há competição } \\
\text { suficiente para a oferta dos demais produtos. }{ }^{30}\end{array}$ \\
\hline \multicolumn{2}{|l|}{$\begin{array}{l}\text { Em razão das economias de escopo, os bancos } \\
\text { conseguem praticar taxas que isolam os seus } \\
\text { produtos dos demais substitutos no mercado. }{ }^{31}\end{array}$} \\
\hline \multicolumn{2}{|r|}{ Brasil } \\
\hline $\begin{array}{l}\text { Considerar cada produto como um mercado } \\
\text { específico seria desprezar a substituibilidade } \\
\text { e os vasos comunicantes entre os diversos } \\
\text { produtos do ponto de vista da oferta e as vendas } \\
\text { casadas de produtos e serviços bancários, em } \\
\text { que um pacote de serviços é transacionado com } \\
\text { uma tarifa única menor que a soma das tarifas } \\
\text { dos serviços ofertados individualmente. }{ }^{32}\end{array}$ & $\begin{array}{l}\text { Apesar de ser provável que o cliente contrate vários } \\
\text { serviços em um só banco, atualmente os consumidores } \\
\text { desagregam os serviços financeiros consumidos e } \\
\text { provavelmente passariam a adquirir produtos em } \\
\text { outras instituições se o preço de um produto de sua } \\
\text { cesta aumentasse. }{ }^{33}\end{array}$ \\
\hline $\begin{array}{l}\text { Há uma tendência natural do correntista em } \\
\text { reduzir os custos de procura na aquisição de } \\
\text { outros produtos financeiros, contratando tais } \\
\text { produtos, portanto, no banco em que possui } \\
\text { conta corrente. }{ }^{34}\end{array}$ & $\begin{array}{l}\text { Os custos de transação de lidar com mais de um } \\
\text { banco foram reduzidos significativamente com a } \\
\text { disponibilização de diversos serviços na internet e em } \\
\text { terminais de autoatendimento. }{ }^{35}\end{array}$ \\
\hline $\begin{array}{l}\text { As políticas de precificação adotadas pelos } \\
\text { bancos reforçam os efeitos de lock in ao incluir, } \\
\text { por exemplo, entre os critérios de precificação, } \\
\text { o tempo de relacionamento do cliente com o } \\
\text { banco. }{ }^{36}\end{array}$ & $\begin{array}{l}\text { Atualmente, as instituições financeiras têm acesso a } \\
\text { informações suficientes de um potencial cliente caso } \\
\text { esse deseje adquirir um produto ou serviço. Assim, } \\
\text { os clientes podem "transferir" sua reputação para a } \\
\text { instituição que desejar. }{ }^{37}\end{array}$ \\
\hline $\begin{array}{l}\text { O cliente bancário, ao se relacionar com apenas } \\
\text { uma instituição, constrói uma reputação que } \\
\text { não pode ser transferida para outra instituição. }{ }^{38}\end{array}$ & $\begin{array}{l}\text { A padronização da nomenclatura dos serviços } \\
\text { bancários estabelecida pelo Banco Central por meio da } \\
\text { Resolução no } 3.5 \mid 8 / 2008 \text { facilitou a comparação entre } \\
\text { os serviços oferecidos pelos bancos, contribuindo para } \\
\text { a redução dos custos de transação. }{ }^{39}\end{array}$ \\
\hline
\end{tabular}

25 Harvey Rosenblum, John Di Clemente and Kit O’Brian. “The product market in commercial banking: Cluster's last stand". Federal Reserve Bank of Chicago.

26 OCDE. Mergers in Financial Services. 2000. 
84. Entendo e respeito os argumentos favoráveis e contrários à definição da dimensão produto como uma cesta de serviços. Para o presente caso, eu particularmente entendo que a opção mais adequada seria não agregar os produtos em cesta, pelas seguintes razões:

1. Ainda que a relação entre consumidores e bancos seja caracterizada por uma cesta de serviços, em decorrência principalmente de subsídios cruzados por parte da oferta, gerando um efeito de "lock in", e de custos de transação que dificultam a contratação, pelo consumidor, dos diferentes produtos simultaneamente em diversas instituições financeiras, esses fatores não se aplicam a todos os serviços oferecidos pelos bancos, tais como: financiamento de veículos, financiamento de imóveis, seguros, previdência privada, consórcios, entre outros.

2. Esses efeitos são ainda menos intensos para médias e grandes empresas, que compõem parte relevante da demanda por serviços bancários e que podem mais facilmente diluir os custos de transação.

3. Se o efeito cluster fosse tão forte como normalmente se acredita, as estruturas de mercado nos produtos específicos que compõem cada cesta não deveriam variar significativamente entre os diferentes produtos. Entretanto, as evidências colhidas das participações de mercado por produto não demonstram ser esse exatamente o caso, ao menos para determinadas cestas de produtos definidas pela Superintendência Geral e utilizadas pelo Departamento de Estudos Econômicos em seus testes (vide tabela abaixo).

4. Tratar os produtos em cestas fragiliza a aplicação dos tradicionais testes quantitativos de screening e a análise de eventuais eficiências requeridas decorrentes da operação. Conforme bem alertaram as

27 Harvey Rosenblum, John Di Clemente and Kit O’Brian. “The product market in commercial banking: Cluster's last stand". Federal Reserve Bank of Chicago.

28 OCDE. Mergers in Financial Services. 2000.

29 United States vs. Philadelphia National Bank et al. Julgado em 17 de junho de 1963.

30 OCDE. Mergers in Financial Services. 2000.

United States vs. Philadelphia National Bank et al. Julgado em 17 de junho de 1963.

Voto do Conselheiro César Costa Alves de Mattos no AC no 08012.011736/2008-41.

3 Voto do Conselheiro Fernando de Magalhães Furlan no AC no 08012.011303/2008-96.

Voto do Conselheiro César Costa Alves de Mattos no AC nº 08012.011736/2008-41.

Voto do Conselheiro Fernando de Magalhães Furlan no AC no 08012.011303/2008-96.

Voto do Conselheiro César Costa Alves de Mattos no AC nº 08012.011736/2008-41.

Voto do Conselheiro Fernando de Magalhães Furlan no AC nº 08012.011303/2008-96.

Voto do Conselheiro Fernando de Magalhães Furlan no AC no 08012.011303/2008-96.

Voto do Conselheiro Fernando de Magalhães Furlan no AC noo 08012.011303/2008-96. 
Requerentes por meio do documento "Considerações a Respeito da Análise Econômica do AC Bradesco/HSBC" da LCA Consultores (SEI 0179449), testes como o UPP, GUPPI e CPPI, instruídos nos autos, pressupõem considerar os produtos de forma individualizada, não agrupada. ${ }^{40}$

5. O HSBC é um banco especializado em um nicho específico do mercado: alta renda. ${ }^{41}$ Pode-se inferir, com base nisso, que esse banco experimenta uma demanda diferenciada por determinados produtos e serviços específicos. Dessa forma, agregar produtos em cesta pode trazer como consequência a subestimação do poder de mercado do HSBC ao diluir sua possível elevada participação em determinado produto específico juntamente com os demais produtos agregados em uma hipotética cesta, e vice-versa.

Tabela 6

Ranking por Banco para Produtos Selecionados

\begin{tabular}{|l|cccccccc|}
\multicolumn{1}{r}{ BANCO } & $\begin{array}{c}\text { Depósitos à } \\
\text { vista }\end{array}$ & $\begin{array}{c}\text { Crédito Livre } \\
\text { PF }\end{array}$ & $\begin{array}{c}\text { Consignado } \\
\text { PF }\end{array}$ & $\begin{array}{c}\text { Financiamento } \\
\text { Habitacional }\end{array}$ & $\begin{array}{c}\text { Financiamento } \\
\text { Veículos }\end{array}$ & $\begin{array}{c}\text { Cartão de } \\
\text { Crédito }\end{array}$ & $\begin{array}{c}\text { Seguros de } \\
\text { Pessoas }\end{array}$ & $\begin{array}{c}\text { Dep. prazo e } \\
\text { Poupança }\end{array}$ \\
\hline BB & $1^{2}$ & $2^{2}$ & $1^{2}$ & $4^{2}$ & $1^{2}$ & $2^{2}$ & - & $2^{2}$ \\
Itaú & $2^{2}$ & $1^{2}$ & $3^{2}$ & $2^{2}$ & $3^{2}$ & $1^{2}$ & $1^{2}$ & $3^{2}$ \\
Bradesco & $3^{2}$ & $3^{2}$ & $4^{2}$ & $3^{2}$ & $4^{2}$ & $3^{2}$ & $2^{2}$ & $4^{2}$ \\
CEF & $4^{2}$ & $5^{2}$ & $2^{2}$ & $1^{2}$ & $5^{2}$ & $6^{2}$ & $3^{2}$ & $1^{2}$ \\
Santander & $5^{2}$ & $4^{2}$ & $5^{2}$ & $5^{2}$ & $2^{2}$ & $4^{2}$ & - & $5^{2}$ \\
HSBC & $6^{2}$ & $6^{2}$ & $6^{2}$ & $6^{2}$ & $6^{2}$ & $5^{2}$ & $4^{2}$ & $6^{2}$ \\
\hline
\end{tabular}

- Participações de mercado considerando todas as instituições.

Fonte: dados informados pelas Requerentes.

85. Portanto, com relação à definição de mercado relevante na dimensão produto, considerarei nesta análise que cada produto e/ou serviço bancário constitui um mercado de produto distinto, devendo ser analisado individualmente. Dessa forma, os produtos/serviços bancários não devem ser

40 Especificamente, o documento argumenta que "outra preocupação relevante quanto ao uso das simulações no caso em tela diz respeito ao fato de elas terem sido elaboradas considerandose cestas de produtos. Há, aqui, dois reparos. Primeiro, o modelo de Bertrand supõe que cada firma produz um único bem - a consideração de vários produtos, com atributos os mais variados e distintos, não condiz com o ambiente de Bertrand. Segundo, ainda que se desconsiderasse essa restrição, a composição das cestas faz um amálgama entre produtos incomparáveis em seus diversos atributos - notadamente quando se compõem numa mesma cesta produtos de captação, produtos de crédito e mesmo produtos não bancários".

41 As Requerentes informaram que "o Bradesco tem uma base mais capilarizada, e atinge um público de clientes de renda média mais baixa comparativamente ao HSBC - enquanto o saldo médio em conta corrente no Bradesco é [ACESSO RESTRITO ÀS REQUERENTES], no HSBC é de [ACESSO RESTRITO ÀS REQUERENTES], conforme dados do Sisbacen (SEI 0203119). 
agregados em "clusters" ou cesta de produtos, de modo a permitir que sejam identificados com mais clareza os mercados em que há potencial problema concorrencial. Haverá, contudo, algumas agregações de produtos com razoável grau de substitutibilidade, seja pelo lado da oferta ou da demanda, conforme proposto pela própria Superintendência Geral.

86. Destaco que a definição ora adotada, produto a produto, vai ao encontro do entendimento proferido na relatoria do conselheiro Fernando de Magalhães Furlan (AC 08012.011303/2008-96, requerentes Banco Itaú S.A. e Unibanco).

87. Dessa forma, defino os mercados relevantes de produto detalhados a seguir: ${ }^{42}$ i. depósitos à vista; ii. depósitos a prazo e poupança; iii. cartão de crédito; iv. financiamento de veículos a pessoas físicas; v. crédito de livre utilização a pessoas físicas; vi. empréstimos consignados; vii. empréstimos direcionados à habitação; viii. crédito de livre utilização a pessoas jurídicas; ix. empréstimo em moeda estrangeira, $x$. empréstimo direcionado a pessoas jurídicas (BNDES e Rural); xi. asset management, xii. grupo de seguros pessoas; xiii. previdência privada; xiv. capitalização; xv. consórcios de imóveis; xvi. consórcios de automotores; xvii. consórcio de pesados; e xviii. cobrança bancária.

\section{VI.2.1.1 Depósitos à vista}

88. O depósito à vista é um produto destinado a pessoas físicas e jurídicas que consiste na captação de recursos não remunerados, que podem permanecer no banco por tempo indeterminado e são de livre utilização pelo consumidor. Ele é um dos principais produtos das instituições financeiras, sendo utilizado pelos clientes como forma de guarda e custódia de seus recursos. Tal forma de depósito também é o meio menos oneroso de captação de recursos pelos bancos.

42 A Superintendência-Geral definiu 25 mercados relevantes de produto. Os mercados de produto definidos pela SG e não considerados neste voto são: Antecipação de Recebíveis (limitação nos dados); Programas de Fidelização Individual (os dados usados como proxy não parecem ser comparáveis); Arranjos de Pagamento (não quantificados) e Corretagem de Seguros (não quantificado). Além disso, foram realizadas as seguintes agregações: Financiamento Habitacional PJ e Financiamento Habitacional PF (há substitutibilidade pela oferta e o mercado é regulado); Financiamento Rural PJ e Financiamento BNDES PJ (os créditos são direcionados a PJ e o mercado é regulado) e Gestão de Fundos de Investimento e Administração de Fundos de Investimento (os produtos desses mercados são oferecidos em conjunto aos clientes). 


\section{VI.2.1.2 Depósitos a prazo e poupança}

89. Depósitos a prazo e poupanças consistem em formas de captação remunerada de recursos. No caso da poupança, os valores depositados são remunerados mensalmente e podem ser movimentados a qualquer tempo. Nos depósitos a prazo, estabelece-se um prazo determinado de imobilidade dos recursos ou validade do investimento, variando a remuneração auferida pelo cliente conforme o valor, o prazo e o risco do investimento.

\section{VI.2.1.3 Cartão de crédito}

90. Cartões de crédito são instrumentos de pagamento destinados a pessoas físicas ou jurídicas que possibilitam o pagamento à vista ou parcelado de produtos e serviços, obedecidos requisitos predeterminados, tais como validade dos plásticos, abrangência e limite do cartão.

\section{VI.2.1.4 Cobrança bancária}

91. A cobrança bancária é um conjunto de serviços que tem por objetivo oferecer aos clientes dos bancos meios para facilitar o recebimento de valores referentes às vendas de produtos ou serviços de uma empresa, mediante a emissão de boleto de cobrança. Existem duas modalidades de boletos bancários que podem ser emitidos: (i) com registro, em que o cedente presta todas as informações da transação e do sacado para a instituição financeira e esta faz a emissão do boleto; e (ii) sem registro, no qual o próprio cedente é responsável por preencher e enviar o boleto ao sacado.

\section{VI.2.1.5 Crédito de livre utilização - pessoa física}

92. Constituído pelas modalidades de crédito que podem ser livremente aplicadas pelas instituições bancárias e livremente utilizadas para qualquer destinação pelos clientes. Na presente análise, foram incluídos nesse mercado: (i) o cheque especial; (ii) o crédito direto ao consumidor (CDC), exceto para aquisição de veículos; e (iii) o crédito pessoal não consignado. 


\section{VI.2.1.6 Empréstimo consignado - pessoa física}

93. O empréstimo consignado para pessoas físicas se diferencia dos demais apresentados no item anterior por estabelecer um desconto no salário do devedor, com o objetivo de pagar a dívida junto à instituição financeira credora. Tal mecanismo de retenção de parte da renda e de sua remessa direta ao banco pelo empregador diminui consideravelmente o risco de inadimplemento pelo consumidor, e, em consequência, as taxas de juros pagas pelo cliente.

\section{VI.2.1.7 Financiamento habitacional}

94. Refere-se ao empréstimo direcionado para financiamento habitacional. Por determinação do Conselho Monetário Nacional - CMN, 65\% dos recursos captados pelos bancos por meio da caderneta de poupança devem ser direcionados ao financiamento habitacional, tornando inviável para a instituição financeira o redirecionamento desse recurso para oferta de outros tipos de crédito demandados pelos consumidores. Como o próprio imóvel financiado é dado como garantia ao banco, as taxas de juros deste tipo de crédito são diferenciadas, dificultando sua substitutibilidade também pela ótica da demanda. Embora haja diferenças em termos de destinação dos recursos entre o financiamento para pessoas físicas e para pessoas jurídicas, ambos foram considerados aqui no mesmo mercado relevante de produto, tendo em vista a substitutibilidade pelo lado da oferta e também por se tratar de um crédito direcionado. ${ }^{43}$

\section{VI.2.1.8 Financiamento para aquisição de veículos - pessoa física}

95. Nesse mercado estão agrupados o CDC para a aquisição de veículos e o arrendamento mercantil (leasing). A principal diferença entre o CDC para

43 Enquanto o crédito para pessoa jurídica tem como objetivo financiar a construção de um imóvel para venda de suas unidades, o crédito para pessoa física possibilita ao cliente adquirir um imóvel para o seu próprio uso. O Conselho Monetário Nacional - CMN estipulou que $65 \%$ dos recursos obtidos pelos bancos com a caderneta de poupança devem ser direcionados ao financiamento habitacional. 
aquisição de veículos e o arrendamento mercantil consiste no fato de que, no CDC, a propriedade do bem desde o princípio pertence ao cliente (com o bem sendo alienado em favor do banco), enquanto que no arrendamento mercantil a propriedade pertence ao banco e só será transferida, se o cliente assim optar, no final do contrato. Ainda assim, os dois produtos são substitutos tanto pela perspectiva da oferta quanto da demanda.

\section{VI.2.1.9 Empréstimos direcionados - Financiamento rural e repasses $B N D E S$ a pessoa jurídica}

96. A jurisprudência do Cade tem agrupado o financiamento rural e os financiamentos com recursos do Banco Nacional do Desenvolvimento Econômico e Social (BNDES) em um único mercado de empréstimos direcionados a pessoa jurídica, por serem operações de crédito vinculadas, destinadas à consecução de políticas de desenvolvimento.

\section{VI.2.1.10 Crédito de livre utilização - pessoa jurídica}

97. Na presente operação, dez produtos foram agrupados nessa cesta, quais sejam: (i) desconto em duplicatas; (ii) capital de giro; (iii) conta garantia; (iv) vendor; (v) compror; (vi) financiamento com interveniência - CDCI; (vii) aquisição de crédito; (viii) antecipação a fornecedores; (ix) aquisição de bens e serviços; e (x) cheque especial. A agregação desses produtos devese ao fato de que, além da liberdade para alocação do crédito por parte do cliente, todos os produtos acima mencionados obtêm funding nos recursos de livre utilização por parte do banco captados pelo depósito à vista, a prazo ou poupança, de forma que, tanto pela demanda quanto pela oferta, tais créditos podem ser considerados, em algum nível, substitutos.

\section{VI.2.1.11 Empréstimos em moeda estrangeira - pessoa jurídica}

98. Os empréstimos em moeda estrangeira para pessoa jurídica incluem financiamento à exportação (pré-pagamento de exportação), financiamento à exportação (ACE e ACC) e financiamento à importação. Conforme precedente 
do Cade ${ }^{44}$ essas operações são substituíveis entre si sob o ponto de vista do consumidor que opera com comércio exterior, motivo pelo qual foram reunidas em um mesmo mercado relevante. Trata-se de operações atreladas a moedas estrangeiras, sujeitas, portanto, à variação cambial. Essa característica, bem como a destinação específica (comércio exterior), faz com que esse tipo de crédito não tenha substituto próximo.

\section{VI.2.1.12 Gestão de recursos de terceiros (asset management)}

99. A jurisprudência mais recente do Cade inclui as atividades de administrador fiduciário e de gestor de recursos em um mesmo mercado relevante de gestão de recursos de terceiros. O administrador fiduciário é o responsável pelas atividades gerenciais e operacionais do fundo, entre elas sua constituição, aprovação do seu regulamento e a divulgação de informações para a Comissão de Valores Mobiliários - CVM e para os investidores. O gestor de recursos, por sua vez, possui a função de gerir os ativos financeiros da carteira do fundo, com poderes para negociar e contratar ativos financeiros em nome do fundo, bem como exercer o direito de voto decorrente dos ativos financeiros detidos pelo fundo.

\section{VI.2.1.13 Previdência privada}

100. A previdência privada tem como objetivo complementar a renda do contribuinte após a sua aposentadoria. Usualmente, os planos têm contribuição mensal com data predefinida, mas o cliente ou o seu empregador também podem realizar aportes esporádicos. Após o período de arrecadação, o valor acumulado pode ser resgatado em sua integralidade ou convertido em renda para o contribuinte.

44 Voto do Conselheiro Fernando de Magalhães Furlan no Ato de Concentração nº 08012.011303/2008-96 (Banco Itaú S.A. e Unibanco). Julgado em 18. 8.2010. 


\section{VI.2.1.14 Serviços de capitalização}

101. O título de capitalização é uma forma de poupança de longo prazo com baixo rendimento, mas com um caráter lotérico de sorteio de prêmios, comercializado por sociedades de capitalização autorizadas pela SUSEP. O capital exigido do cliente para a sua aquisição pode ser dado em uma única vez (plano único) ou de forma parcelada (plano mensal) e o prazo do plano é variável, mas não pode ser inferior a um ano. Os títulos podem prever um período de carência, no qual o portador não poderá resgatar o valor despendido. Além disso, em caso de resgate antecipado, as sociedades de capitalização poderão estipular uma penalidade de até $10 \%$ do capital já constituído.

\section{VI.2.1.15 Seguros}

102. Pelo contrato de seguro, um agente (segurado) busca se proteger de eventos futuros e incertos por meio de um prêmio pago a outro agente (segurador), que indenizará o segurado caso os eventos acordados no contrato venham a ocorrer dentro de um prazo determinado.

103. Em consonância com a jurisprudência do $\mathrm{CADE}^{45}$ cada grupo de seguros tem sido definido como um mercado relevante de produto em separado, quais sejam: (i) patrimonial; (ii) riscos especiais; (iii) responsabilidades; (iv) cascos; (v) automóvel; (vi) transportes; (vii) riscos financeiros; (viii) crédito; (ix) pessoal coletivo; (x) habitacional; (xi) rural; (xii) pessoas - individual; (xiii) marítimos; (xiv) aeronáuticos; e (xv) outros. Considerando que a presente operação só provoca sobreposição no grupo de seguros de pessoas - individual, apenas este mercado será objeto de análise.

45 AC no 08012.011303/2008-96 (Itaú S.A. e Unibanco), 08012.007214/2009-26 (Itaú Unibanco S.A. e Porto Seguro S.A.), AC nº 08012.005526/2012-39 (Banco do Brasil S.A., BB Seguros Participações S.A. e Mapfre Vera Cruz Seguradora S.A.), AC no 08700.002270/2013-01 (IRB Brasil Resseguros S.A., Bradesco Auto/RE Companhia de Seguros, BB Seguros Participações S.A., Itaú Seguros S.A., Itaú Vida e Previdência S.A. e Fundo de Investimentos e Participação Caixa Barcelona) e Ato de Concentração no 08700.006876/2014-98 (ACE INA International Holdings, Ltda. e Itaú Seguros Soluções Corporativas S.A.). 


\section{VI.2.1.16 Consórcio}

104. O consórcio é um fundo comum formado com a contribuição mensal de um grupo de pessoas destinado a proporcionar a cada consorciado a aquisição de um bem ou um conjunto de bens, previamente fixado no contrato. As administradoras de consórcios não precisam ser instituições financeiras, mas sua atividade é regulada pela Lei no 11.795/2008 e pelo Banco Central do Brasil. Do ponto de vista dos clientes, o consórcio é um meio bastante atrativo para viabilizar a aquisição de um bem em razão de a taxa de administração ser inferior aos juros usualmente cobrados pelos bancos.

105. Considerando as sobreposições horizontais verificadas entre as Requerentes, serão objeto de análise os segmentos de (i) bens imóveis; (ii) tratores, equipamentos rodoviários, máquinas e equipamentos agrícolas, embarcações, veículos automotores destinados a transporte coletivo; e (iii) veículos automotores não incluídos no segmento anterior, exceto motocicletas e motonetas.

\section{VI.2.2 Dimensão Geográfica}

106. Quanto à dimensão geográfica do mercado relevante, em que pese o argumento de atuação em nível nacional dos bancos, a política comercial idêntica para todas as localidades e as facilidades tecnológicas atualmente oferecidas pelas instituições aos clientes, que reduzem a necessidade da presença física das agências bancárias em algumas situações, sou da opinião de que o mercado geográfico é mais restrito em função da forte influência dos custos de procura existentes nesse mercado. Na perspectiva do mercado pelo lado da oferta, poderia até ser cabível um dimensionamento em nível nacional para o mercado relevante. Entretanto, se considerarmos a questão pela ótica da demanda, chegamos a conclusões diferentes. Cabe lembrar que o conceito teórico de mercado relevante se refere ao menor conjunto de produtos ou espaço geográfico para os quais seria possível sustentar um aumento lucrativo de preços sem ser contestado por eventuais concorrentes.

107. A premissa geral do argumento aqui defendido é a de que seria pouco razoável supor que determinado cliente de serviços bancários se deslocaria até uma agência localizada em outro município (ou em outra unidade federativa) distinto daquele onde reside, com o estrito propósito de abrir uma conta 
corrente ou formalizar uma operação de crédito com um banco ausente em seu município de origem. Esse é, na realidade, um problema típico de setores que operam no varejo, ou, mais precisamente, que lidam diretamente com o consumidor final, como supermercados, lojas de departamento, prestadores de serviços etc. Em tais setores, o cliente normalmente precisa despender elevados custos de deslocamento e de oportunidade (tempo) para fugir de um aumento de preços por parte de um agente com poder de mercado.

108. No setor bancário, no entanto, essa dificuldade é agravada pelo relativamente baixo preço unitário do serviço/produto percebido pelo consumidor (ou seja, não se trata da compra de um carro ou eletrodoméstico, cujo deslocamento pode compensar), e pelo perfil dos clientes de pequeno porte (pessoas físicas, micro e pequenas empresas), cujos produtos prioritariamente demandados (depósitos, saques e operações de crédito) requerem a ida a uma agência bancária ou até mesmo o contato com funcionários do banco. Pela sua fragilidade e pela forte assimetria de informação no setor bancário, esse segmento do mercado está mais sujeito a eventual exercício de poder de mercado por parte dos bancos. Como muito bem observado pela Superintendência-Geral, ${ }^{46}$ "Os demais consumidores pessoas físicas e pequenas e médias empresas, por sua vez, tendem a ser mais sensíveis ao problema da assimetria de informação. Além disso, costumam depender muito mais das agências bancárias para contratar e utilizar os serviços, têm menos condições de realizar pesquisas de preços e evitam trocar de banco ou contratar serviços em diferentes bancos. São, portanto, menos sensíveis aos aumentos de preços do que as grandes empresas".

109. Naturalmente, essa discussão dialoga com a análise dos custos de entrada para rivais, que faço mais à frente neste voto, pois pressões de aumento de preços podem ser anuladas não só pelo desvio da demanda para outra localidade, mas pela entrada de um concorrente mais agressivo na mesma localidade. Adianto, no entanto, que me parecem haver barreiras suficientes à entrada nos mercados de parte considerável dos produtos, ou seja, daqueles que dependem de uma agência no local. A barreira não decorre necessariamente de custos de instalação de uma agência, que não me parecem tão relevantes, mas da possibilidade de captura ou conversão, por um banco entrante, de clientes residentes em um determinado município que já possuam conta em outro banco. Ou seja, a baixa rivalidade do setor acaba gerando, também, barreiras à entrada.

\footnotetext{
46 Anexo ao Parecer Técnico no 12/2016/CGAA02/SGA1/SG/CADE (SEI 0183985).
} 
110. No ato de concentração entre Banco do Brasil e Banco Nossa Caixa (AC 08012.011736/2008-41) encontramos precedente para essa delimitação do mercado geográfico como municipal, pois o voto do conselheiro relator César Mattos considerou que, para clientes de porte reduzido, o mercado é melhor definido localmente, determinando remédios destinados a municípios com elevada concentração.

111. Por fim, também reforça minha convicção a existência de pelo menos dois estudos acadêmicos ${ }^{47}$ que, ao analisar poder de mercado no setor bancário, realizam testes com o mercado relevante em nível municipal. Portanto, passo a considerar como dimensão geográfica para o mercado relevante da presente operação o nível municipal.

\section{VI.3 Da Possibilidade de Exercício de Poder de Mercado}

112. Em nível nacional, a operação gera sobreposição horizontal nas atividades das Requerentes em todos os produtos definidos acima. ${ }^{48}$

113. Para avaliar a sobreposição segundo a definição de mercado relevante que considera a dimensão geográfica como sendo municipal, considerando os 526 municípios em que há agências do HSBC e 18 produtos bancários distintos, seria necessário avaliar a possibilidade de exercício de poder de mercado em 9.468 mercados distintos.

114. No entanto, pela clara inviabilidade técnica de se empreender tal análise dentro do período legalmente exigido para a decisão, seja por falta de dados em nível local, seja pela grande quantidade de mercados a serem analisados, opto por manter a estratégia da Superintendência-Geral de utilizar dados em nível nacional para a etapa de filtragem dos produtos potencialmente problemáticos. Dado que o mercado geográfico foi definido

47 Martins, B. Local Market Structure and Bank Competition: evidence from the Brazilian auto loan market. Working Paper. Banco Central do Brasil. 2012. Coelho, C. et al.

${ }^{\mathrm{D}} \mathrm{P}$ Public Banks Compete with Private Banks? Evidence from Concentrated Local Markets in Brazil. Texto para Discussão no 551. Departamento de Economia, PUC-Rio. 2011.

48 Em seu Parecer Técnico nº 12/2016/CGAA02/SGA1/SG/CADE, a Superintendência-Geral identificou também integração vertical entre as atividades de (i) seguros de pessoas e corretagem de seguros; (ii) seguros de pessoas e resseguros; (iii) emissão de cartões de crédito e arranjos de pagamento; e (iv) emissão de cartões de crédito e programas de fidelização individual. Contudo, essas integrações verticais dizem respeito a produtos não definidos como mercados relevantes na presente análise. 
como municipal, tal procedimento implica a existência de um viés no sentido de subestimar o poder de mercado das Requerentes em diversas localidades.

115. Além de trabalhar com dados em nível nacional, outra opção metodológica da SG, e que também optamos por acompanhar, foi a de considerar apenas os seis maiores players do setor (Banco do Brasil, Caixa Econômica, Itaú Unibanco, Santander e Bradesco e o HSBC Brasil $)^{49}$ nos mercados de produtos de intermediação financeira (ou naqueles prestados exclusivamente ou majoritariamente por instituições financeiras, como é o caso de depósitos, cobrança bancária ou concessão de crédito). Desprezar a chamada "franja" do mercado traz como consequência uma elevação artificial da participação de mercado das Requerentes, gerando, portanto, um viés contrário, que atenua o problema da provável subestimação de seu poder para parte dos mercados locais. Digo "parte dos mercados" porque, para os mercados relevantes de produtos ou serviços não financeiros, apesar de também se constatar uma concentração muito elevada de participação em poder dos grandes bancos, há a presença de players não bancários com efetiva capacidade de rivalizar no mercado, tais como seguradoras, gestoras de recursos e administradores de consórcios. Com o objetivo de não desconsiderar erroneamente a rivalidade exercida pelas instituições especializadas nesses mercados, as participações de mercado nesses produtos não financeiros serão calculadas com base no faturamento total do mercado..$^{50}$

116. Temos, portanto, um viés favorável e um viés contrário às Requerentes, e não temos como saber a direção do resultado líquido desses dois vieses. Por essa razão, conferindo maior peso ao descasamento entre o que entendemos ser o mercado relevante e os dados disponíveis para análise, considero razoável adotar critérios mais conservadores que os adotados pela SG para as linhas de corte dos índices de HHI: enquanto a Superintendência optou por descontinuar a análise produto a produto ${ }^{51}$ tendo como referências as linhas

49 Segundo a Superintendência-Geral, esse procedimento se justifica pelas diferenças de escala entre os maiores bancos brasileiros e os demais concorrentes no mercado, pela capilaridade da rede de atendimento desses bancos, pelo portfólio de produtos e pelo reconhecimento das próprias Requerentes de quais seriam os concorrentes mais próximos do Bradesco no mercado (Anexo 1, págs. 48 e 49).

50 Os produtos para os quais foram considerados apenas a participação dos cinco maiores bancos mais o HSBC foram os seguintes: i) depósitos à vista; ii) poupança e depósitos a prazo; iii) cobrança bancária; iv) crédito de livre utilização - pessoa física; v) empréstimos consignados - pessoa física; vi) financiamento habitacional; vii) financiamento para a aquisição de veículos - pessoa física; viii) crédito de livre utilização - pessoa jurídica; e ix) empréstimo em moeda estrangeira - pessoa jurídica.

51 Anexo ao Parecer Técnico nº 12/2016/CGAA02/SGA1/SG/CADE (SEI 0183985). 
de corte adotadas pela DGCOMP, ${ }^{52}$ este Gabinete adotará os parâmetros do guia de análise antitruste da Federal Trade Commission (Estados Unidos), cujos padrões reproduzo abaixo:

Baseadas em suas experiências, as Agências geralmente classificam os mercados em três tipos:

(i) Mercados não concentrados: HHI abaixo de 1500

(ii) Mercados moderadamente concentrados: HHI entre 1500 e 2500

(iii) Mercados altamente concentrados: HHI acima de 2500

As Agências utilizam as seguintes normas gerais para os mercados relevantes que definiram:

(i) Pequena alteração na concentração: operações envolvendo uma variação do HHI inferior a 100 pontos provavelmente não gerarão efeitos anticoncorrenciais e, normalmente, não necessitam de uma análise mais aprofundada.

(ii) Mercado não concentrados: operações que resultem em mercados não concentrados (HHI abaixo de 1.500) provavelmente não gerarão efeitos anticoncorrenciais e, normalmente, não necessitam de uma análise mais aprofundada.

(iii) Mercados moderadamente concentrados: operações que resultem em mercados moderadamente concentrados (HHI entre 1.500 e 2.500) e que envolvam uma variação do $\mathrm{HHI}$ de mais de 100 pontos sugerem potencial para geração de efeitos anticoncorrenciais e, normalmente, demandam uma análise mais aprofundada.

(iv) Mercados altamente concentrados: operações que resultem em mercados moderadamente concentrados (HHI acima de 2.500) e que envolvam uma variação do HHI entre 100 e 200 pontos sugerem potencial para geração de efeitos anticoncorrenciais e, normalmente, demandam uma análise mais aprofundada. Para operações que resultem em mercados com HHI acima de 2.500 pontos e quem envolvam variação do HHI acima de 200 pontos presume-se poder de mercado. Essa presunção poderá ser refutada por evidências persuasivas em sentido contrário.

(Tradução Livre, destaques acrescentados)

52 Directorate-General for Competition da Comissão Europeia. 
117. Portanto, em adição ao critério tradicional de market share das Requerentes superior a $20 \%$ no cenário pós-fusão, presumirei que há possibilidade de exercício de poder de mercado e nexo de causalidade entre a operação e a existência de problemas concorrenciais, justificando análise mais aprofundada, nos mercados que registrarem, nos testes com dados em nível nacional, valores de HHI entre 1.500 e 2.500 pontos, combinado com uma variação de HHI superior a 100 pontos. ${ }^{53} 54$

\section{IV.3.1 Sobreposições Horizontais}

118. Primeiramente, apresentamos o resultado da análise de HHI e market share para os dezoito mercados de produto identificados, conforme os parâmetros descritos anteriormente, marcados em cinza aqueles cujos resultados dos testes ultrapassam os valores críticos:

53 A linha de corte de 100 pontos para mercados moderadamente concentrados também está de acordo com a proposta do novo Guia de Análise de Atos de Concentração Horizontal do CADE, disponível em http://www.cade.gov.br/acesso-a-informacao/publicacoesinstitucionais/guias_do_Cade/guia-guia-de-ac-horizontal.pdf.

54 Cabe aqui um esclarecimento adicional quanto a esse ponto. No Despacho Decisório no 4/2016/ GAB1/CADE, foi afirmado que, "embora os níveis de participação de mercado e do índice HHI sejam afetados pela utilização de dados apenas das seis maiores instituições bancárias, o valor calculado para a variação do índice HHI, que efetivamente aponta o nexo de causalidade, é pouco ou nada sensível a essa opção metodológica". Essa informação foi refutada pelas Requerentes, que demonstraram que a elevação na variação de HHI decorrente da exclusão da "franja" do mercado pode ser sim relevante para determinados produtos, quando adotados 100 pontos como nível de corte para presumir nexo de causalidade, de tal forma que alguns mercados deixariam de ser classificados como problemáticos do ponto de vista concorrencial quando se considera o mercado desses produtos como um todo. Reconheço a qualidade do argumento e a correção dos cálculos efetuados pelas Requerentes. Entretanto, para análise da presente operação, não me parece uma solução razoável considerar os valores totais dos mercados naqueles produtos ofertados exclusivamente ou majoritariamente por instituições financeiras. Se tomarmos como exemplo o próprio "Crédito Livre de Pessoa Física", veremos que, entre as principais instituições classificadas como "outras", que compõem a denominada "franja" do mercado, constam bancos de atuação focada em nichos específicos de mercado ou restritos a determinadas regiões geográficas, como, por exemplo, o Banco do Nordeste e o Banrisul. Irreal supor que um banco de atuação restrita ao Rio Grande Sul possa oferecer concorrência efetiva no mercado de crédito a pessoas físicas às agências dos grandes bancos localizados no estado de Goiás, por exemplo. Dessa forma, corrigir a distorção apontada pelas Requerentes (variação do HHI) por meio da inclusão da "franja" do mercado acarretaria problemas analíticos ainda mais pronunciados. Entendo o problema suscitado pelas Requerentes, porém acredito que o mesmo esteja suficientemente endereçado pela utilização dos filtros econômicos (screenings), adicionais à análise tradicional, que adotamos complementarmente para embasar as conclusões acerca da possibilidade de poder de mercado, quais sejam, GUPPI e CPPI, conforme detalhado a seguir. 
Tabela 7

Análise de HHI e Market Share nos Mercados com Sobreposição Horizontal

\begin{tabular}{|l|ccc|c|}
\hline \multicolumn{1}{|c}{ MERCADO RELEVANTE } & HHI Antes & HHI Depois & Variação & Share \\
\hline Adminis tração de Consórcios de Imóveis & 1618 & 1816 & 198 & $18,4 \%$ \\
\hline Saldo em Cobrança com Registro & 2251 & 2446 & 195 & $33,0 \%$ \\
Empréstimo em Moeda Estrangeira & 2877 & 3049 & 172 & $26,4 \%$ \\
Depósitos à Vista & 2284 & 2455 & 171 & $20,5 \%$ \\
Crédito de Livre Utilização PJ & 1990 & 2147 & 157 & $22,1 \%$ \\
Capitalização & 1899 & 2036 & 138 & $35,0 \%$ \\
Crédito de Livre Utilização PF & 2078 & 2211 & 133 & $21,7 \%$ \\
Cartão de Crédito & 2720 & 2841 & 121 & $24,5 \%$ \\
Previdência Privada & 2790 & 2907 & 116 & $31,7 \%$ \\
Administração de Consórcios de Pesados & 1116 & 1226 & 110 & $20,5 \%$ \\
\hline Asset Management & 1468 & 1571 & 103 & $16,4 \%$ \\
Grupo de Seguros Pessoas & 1441 & 1541 & 99 & $17,2 \%$ \\
Depósitos a Prazo e Poupança & 2187 & 2275 & 89 & $16,7 \%$ \\
Administração de Consórcios de Automotores & 1793 & 1853 & 60 & $28,1 \%$ \\
Financiamento de Veículos PF & 2206 & 2260 & 54 & $14,4 \%$ \\
Em préstimo Direcionado Ha bitação & 5154 & 5174 & 21 & $8,7 \%$ \\
Em préstimo Consigna do & 2407 & 2422 & 15 & $14,9 \%$ \\
Empréstimos Direcionados a PJ Rural e BNDES & 2542 & 2557 & 14 & $8,4 \%$ \\
\hline
\end{tabular}

119. Como se pode perceber, 9 dos 18 produtos definidos não passam no teste e poderiam, pelos critérios adotados até aqui, ter sua análise aprofundada. No entanto, ainda preocupado com o descasamento dos dados (nacional versus local), achei prudente complementar a filtragem utilizando, adicionalmente, os resultados dos testes de screening GUPPI (incentivos para aumento unilateral de preços em decorrência da fusão) e CPPI (nível de incentivo para que duas firmas entrem em colusão de paralelismo de preços após a fusão). Isso conferiria menor chance de erro na identificação de mercados problemáticos. Como dito anteriormente, as Requerentes demonstraram que, ao considerarmos apenas os seis grandes bancos, desprezando a "franja" do mercado, provocamos um viés na variação do índice HHI, no sentido de superestimar esse parâmetro. Portanto, a utilização desses testes de screening tende a corrigir o problema, pois atuam no sentido de eliminar produtos e filtrar ainda mais a lista de mercados para os quais será empreendida análise mais aprofundada. Trata-se da utilização de elementos analíticos de natureza complementar, úteis para mitigar o problema apontado pelas Requerentes. 
Em especial, cabe ressaltar a importância da utilização do CPPI no presente contexto, tendo em vista os indícios de escassa rivalidade no setor, conforme discutido no capítulo anterior.

120. Na realização desses testes adicionais de screening, adotei a mesma metodologia utilizada pelo DEE na Nota Técnica nํ09/2016/DEE/CADE, porém aplicados a cada produto individualmente, pois, como já discorrido, a análise em cestas pode camuflar o poder de mercado existente em algum mercado de produto específico. A referência bibliográfica e a explicação detalhada dos testes se encontram disponíveis na nota técnica supramencionada, de lavra do DEE..$^{55}$

121. Com relação às premissas dos testes realizados pelo DEE, houve ainda uma outra mudança: a margem de lucro considerada nas simulações. O DEE construiu dois cenários com margens de $25 \%$ e de $50 \%$. As Requerentes, por sua vez, argumentaram contra, questionando a falta de embasamento para tal premissa, e com base em suas próprias informações contábeis, propuseram a utilização de uma margem pouco superior a $20 \%$.

122. É reconhecido que testes quantitativos como o GUPPI e CPPI são bastante sensíveis ao valor atribuído à margem de lucro das empresas. Não por outro motivo, os resultados encontrados pelo DEE e pelas Requerentes são contrastantes: enquanto o Departamento identificou nexo de causalidade entre a operação e o aumento do poder de mercado (unilateral e coordenado) das empresas fusionadas no cenário menos conservador, as Requerentes concluíram a partir de suas simulações que os baixos valores obtidos com os testes não possibilitavam inferir aumento do poder de mercado, seja unilateral ou coordenado.

123. Embora o DEE tenha concluído que "não é possível descartar a possibilidade de efeitos unilaterais e de efeitos coordenados anticoncorrenciais" decorrentes da operação, ante o impasse gerado pelos resultados das Requerentes apontando em outra direção, a SG optou por não considerar os resultados dos estudos quantitativos em suas conclusões.

124. Tentando enfrentar esse obstáculo, este Gabinete buscou informações adicionais que tornassem possível uma melhor estimativa da margem de lucro dos bancos comerciais no Brasil. O Relatório de Economia Bancária e Crédito 2014, elaborado pelo Banco Central do Brasil, traz em sua Tabela 34 (reproduzida abaixo), denominada "Decomposição do spread bancário

55 Documento SEI (0173242). 
prefixado - Maiores bancos", informações suficientes para calcular uma estimativa da margem dos bancos em termos de operações prefixadas de intermediação financeira dos maiores bancos nacionais.

125. A partir dessas informações do Bacen, obtemos a margem de $30 \%{ }^{56}$ a qual foi utilizada nos testes quantitativos de GUPPI e CPPI. Embora essa margem não englobe a totalidade dos produtos e serviços oferecidos pelos bancos, ela se refere à atividade privativa e primordial dos bancos: a intermediação financeira. Além disso, considero que seja a melhor informação neutra disponível para efeitos do cômputo da margem dos bancos. Por fim, mesmo que haja algum viés decorrente de eventual superestimação da margem para alguns produtos específicos, tal viés tende a ser nulo quando se trata de produtos de crédito massificado, cujos clientes, em sua maioria, não contratam operações com taxas pós-fixadas nas negociações com seus bancos.

126. Para o GUPPI, o critério de corte foi o valor de $5 \%,{ }^{57}$ frequentemente utilizado como valor crítico de SSNIP58 nos testes de monopolista hipotético. Dessa forma, mercados de produto com valores do teste inferiores a $5 \%$ não despertariam preocupações concorrenciais. Novamente, foram destacados os produtos que apresentaram problema concorrencial segundo esse teste:

56 Conforme a fórmula dada por [(p-c)/p], onde "p" corresponde ao valor, em pontos percentuais, da rubrica "Taxa de Aplicação"; e "c" corresponde ao somatório das rubricas "Taxa de Captação", "Custo Administrativo", "Inadimplência", "Compulsório + Subsídio Cruzado + Encargos Fiscais e FGC" e "Impostos Diretos".

57 "The Guidelines say that a merger is unlikely to raise significant unilateral effects concerns if the GUPPI is proportionately small. The Guidelines define "proportionately" - that is, "in proportion to the lost revenues attributable to the reduction in unit sales resulting from the price increase" - but they do not quantify "small." Elsewhere, when discussing market definition and the concept of a "small but significant and non-transitory increase in price," the Guidelines seem to quantify "small" as generally equal to $5 \%$. This suggests that a GUPPI of less than $5 \%$ would be reasonably treated as evidence that "the value of diverted sales is proportionately small" and hence that the proposed merger is unlikely to raise unilateral effects concerns." Scoring Unilateral Effects with the GUPPI: The Approach of the New Horizontal Merger Guidelines (2010).

58 Podendo ser traduzido como pequeno, mas significativos e não transitório aumento nos preços. 
Tabela 8

Resultados do Teste GUPPI

\section{MERCADO RELEVANTE}

GUPPI

\begin{tabular}{|l|r|}
\hline \multicolumn{2}{|c|}{ (SSNIP em \%) } \\
\hline Administração de Cons órcios de Imóveis & $10,1 \%$ \\
Adminis tração de Cons órcios de Automotores & $9,5 \%$ \\
Saldo em Cobra nça corn Registro & $9,2 \%$ \\
Previdência Privada & $9,0 \%$ \\
Capitalização & $7,6 \%$ \\
Empréstimo em Moeda Estrang éra & $7,0 \%$ \\
Cartão de Crédito & $6,7 \%$ \\
Administração de Cons órcios de Pesa dos & $6,6 \%$ \\
Asset Management & $5,7 \%$ \\
Crédito de Livre Utiliza ção PF & $5,6 \%$ \\
Crédito cle Livre Utiliza ção PJ & $5,5 \%$ \\
Financiamento de Veículos PF & $5,4 \%$ \\
\hline Grupo de Seguros Pess oas & $4,9 \%$ \\
Depósitos à Vista & $4,7 \%$ \\
Empréstimo Consignado & $4,5 \%$ \\
Depósitos à Prazo e Poupança & $4,2 \%$ \\
Empréstimos Direcionados a PJ Rural e B NDES & $2,2 \%$ \\
Empréstimo Direciona do Habitação & $2,2 \%$ \\
\hline
\end{tabular}

127. Para o CPPI (que, como dito, consiste em um teste para medir o nível de incentivo que duas firmas têm para que entrem em colusão visando um aumento paralelo de preços) o impacto da operação é tradicionalmente medido pela variação do índice (Delta CPPI), levantando um sinal amarelo para qualquer resultado positivo de variação. Ou seja, não despertariam preocupações concorrenciais mercados de produtos para os quais não houve variação positiva de CPPI. Os resultados estão na Tabela 9 abaixo: 
Tabela 9

Resultado do Teste CPPI

\begin{tabular}{|l|rrr|}
\hline \multicolumn{1}{|c}{ MERCADO RELEVANTE } & CPPI Antes & CPPI Depois & Variação \\
\hline Empréstimo em Moeda Estrangeira & $10,8 \%$ & $14,5 \%$ & $3,7 \%$ \\
Depósitos à Vista & $5,5 \%$ & $9,2 \%$ & $3,6 \%$ \\
Crédito de Livre Utilização PF & $7,4 \%$ & $10,1 \%$ & $2,6 \%$ \\
Cartão de Crédito & $10,1 \%$ & $12,5 \%$ & $2,4 \%$ \\
Depósitos a Prazo e Poupança & $4,9 \%$ & $6,7 \%$ & $1,8 \%$ \\
Asset Management & $7,7 \%$ & $8,8 \%$ & $1,1 \%$ \\
Financiamento de Veícul os PF & $7,3 \%$ & $8,3 \%$ & $1,0 \%$ \\
Grupo de Seguros Pessoais & $6,3 \%$ & $6,7 \%$ & $0,4 \%$ \\
Empréstimo Consignado & $5,7 \%$ & $5,9 \%$ & $0,3 \%$ \\
Crédito de Livre Utilização PJ & $7,3 \%$ & $7,5 \%$ & $0,2 \%$ \\
Empréstimo Direcionado Habitação & $2,3 \%$ & $2,4 \%$ & $0,1 \%$ \\
Administração de Consórcios de Automotores & $4,5 \%$ & $4,5 \%$ & $0,0 \%$ \\
Capitalização & $3,9 \%$ & $3,9 \%$ & $0,0 \%$ \\
Administração de Consórcios de Pesados & $0,0 \%$ & $0,0 \%$ & $0,0 \%$ \\
Empréstimos Direcionados a PJ Rural e BNDES & $2,1 \%$ & $2,1 \%$ & $0,0 \%$ \\
Administração de Consórcios de Imóveis & $2,3 \%$ & $2,3 \%$ & $0,0 \%$ \\
Saldo em Cobrança com Registro & $14,3 \%$ & $14,3 \%$ & $0,0 \%$ \\
Previdência Privada & $8,4 \%$ & $8,4 \%$ & $0,0 \%$ \\
\hline
\end{tabular}

128. Para combinar os resultados dos testes e filtrar, assim, os mercados verdadeiramente problemáticos, optamos por nos preocupar apenas com os produtos que apresentaram, cumulativamente: (i) valores acima dos críticos na análise tradicional (20\% de participação de mercado); (ii) valores acima dos críticos na análise de HHI; e (iii) problemas concorrenciais em ao menos um dos dois critérios adicionais (GUPPI e CPPI), conforme tabela abaixo. 
Tabela 10

Resumo dos Testes

\begin{tabular}{|c|c|c|c|c|c|c|c|c|c|}
\hline MERCADO RELEVANTE & $\begin{array}{l}\text { Participaçāo de } \\
\text { Mercado }\end{array}$ & HHIAntes & HHIDepois & Varią̧̧o & $\begin{array}{c}\text { GUPP } \\
\text { (ISSNP em *) }\end{array}$ & CPPIAntes & CPP1 Depois & Vañạ̧̧ăo & $\begin{array}{l}\text { Produtot tipico de bancos } \\
\text { comeraiais? }\end{array}$ \\
\hline Saldo em Cobrança com Registro & $33,0 \%$ & 2251 & 2446 & 195 & 9,286 & $14,3 \%$ & $14,3 \%$ & $0,0 \%$ & $\operatorname{sim}$ \\
\hline Empréstimo em Moeda Estrangeira & $26,4 \%$ & 2877 & 3049 & 172 & $7,0 \%$ & $10,8 \%$ & $14,5 \%$ & $3,7 \%$ & $\operatorname{sIM}$ \\
\hline Cartāo de Crédito & $24,5 \%$ & 2720 & 2841 & 121 & $6,7 \%$ & $10,1 \%$ & $12,5 \%$ & $2,4 \%$ & $\sin$ \\
\hline Créditio de Livre Utilizą̧ăa PF & $21,7 \%$ & 2078 & 2211 & 133 & $5,6 \%$ & $7,4 \%$ & $10,1 \%$ & $2,6 \%$ & $\operatorname{sim}$ \\
\hline Crédito de Livre Utilizaçăa pJ & $22,1 \%$ & 1990 & 2147 & 157 & $5,5 \%$ & $7,3 \%$ & $7,5 \%$ & 0,26 & $\sin$ \\
\hline Depósitos à Vista & $20,5 \%$ & 2284 & 2455 & 171 & 4,786 & $5,5 \%$ & $9,2 \%$ & $3,6 \%$ & sIM \\
\hline
\end{tabular}

129. É importante ressaltar que, do total de nove produtos passíveis de um escrutínio mais aprofundado de acordo com os critérios de análise tradicionais (HHI e participação acima de 20\%), a utilização dos testes adicionais de screening nos permitiu eliminar três deles, restando apenas seis mercados onde haveria possibilidade de exercício de poder de mercado por parte das Requerentes em decorrência da operação. ${ }^{59}$

130. Assim, entendo pela existência de possibilidade de exercício de poder de mercado, bem como nexo de causalidade entre a presente operação e a potencialidade de problemas concorrenciais, nos produtos: i) depósito à vista, ii) cartão de crédito, iii) crédito de livre utilização PF, iv) crédito de livre utilização PJ, v) empréstimos em moeda estrangeira, e vi) saldo em cobrança com registro.

\section{VI.3.2 Críticas e Limitações com Relação aos Testes de Screening}

131. Antes de proceder com a análise de probabilidade de exercício de poder de mercado, faço aqui um breve resumo das discussões travadas entre o Gabinete 01 e as Requerentes quanto à utilização desses testes.

59 Cabe aqui uma observação com relação ao produto Consórcio de Imóveis, que encabeça a lista de produtos problemáticos em dois dos três critérios de corte aplicados, mas não aparece na lista final de produtos com possibilidade de exercício de poder de mercado. Segundo esclarecido pelas Requerentes, os market shares nesse mercado devem ser calculados conforme o número de cotas comercializadas por cada ofertante. Segundo esse critério, Bradesco e HSBC teriam, em conjunto, 18,4\% de participação de mercado, segundo dados do Bacen, percentual aquém do necessário para presunção de poder de mercado. Do ponto de vista estritamente formal, não caberia considerar a possibilidade de exercício de poder de mercado nesse caso. Porém, tendo em vista as evidências nada desprezíveis de possíveis problemas concorrenciais nos demais testes, em função principalmente da forte liderança do Bradesco na administração de consórcios, adianto que, no desenho de um dos remédios constantes no ACC, esse mercado também foi levado em consideração. 
132. Desde a primeira utilização dos testes de screening na análise do presente ato de concentração, as Requerentes se manifestaram ${ }^{60}$ no sentido de apontar suas limitações teóricas, bem como algumas críticas metodológicas com relação à forma como foram aplicados no âmbito do processo. Primeiramente, foi apontado que a hipótese de competição de Bertrand com produtos diferenciados não seria adequada ao setor bancário em determinados casos, como o mercado de captação (depósitos), por exemplo, onde não há remuneração dos depósitos à vista e a remuneração dos depósitos em poupança são determinados por regulação.

133. No caso da captação de recursos à vista, sem remuneração, entendo que o preço pago pelos clientes pela prestação do serviço de depósito de valores traduz-se na cobrança das tarifas por diversos serviços individuais, como saques, transferências, talões de cheque etc. $\mathrm{O}$ fato de os bancos optarem, em alguns casos, como parte de uma estratégia comercial, conceder descontos nessas tarifas para clientes de maior interesse, provavelmente aqueles com maior saldo médio em conta-corrente ou que compram outros serviços do próprio banco, não significa a inexistência de um preço. Até porque, na hipótese mais remota de isenção total de tarifas, existe ainda o custo de oportunidade do recurso ali depositado, que não remunerado pelo banco ao cliente. Quanto aos depósitos a prazo e poupança, em que há remuneração, o raciocínio seria o mesmo, o preço pode ser facilmente compreendido como o diferencial entre o valor da remuneração e taxa básica de juros da economia, normalmente referenciada no CDI. Ou seja, os bancos remuneram seus clientes valores inferiores aos juros de títulos públicos, e esse "desconto" varia de banco para banco, cumprindo a função do preço. Há sim, portanto, um preço e um mercado a ser considerado para esses produtos, não sendo esse o primeiro caso de "almoço grátis" a que teremos conhecimento na literatura econômica.

134. Outra limitação mencionada diz respeito à dificuldade de se obter informações seguras de custo marginal e/ou custo variável e de se calcular a "diversion ratio" (taxa de desvio), que exige a estimação de elasticidades cruzadas, tarefa nada trivial em termos de esforços e de disponibilidade de dados. Com relação aos custos, como já dito anteriormente, utilizamos informações elaboradas pelo Banco Central. ${ }^{61}$ Sobre as elasticidades, esclareço

60 Considerações a Respeito da Análise Econômica do AC Bradesco/HSBC" da LCA Consultores (SEI 0179449) e posteriormente "Considerações ao Despacho do Conselheiro-Relator", de elaboração da LCA Consultores (SEI 203119).

61 Relatório de Economia Bancária e Crédito 2014. Acessado em 31/5/2016 e disponível em http:// www.bcb.gov.br/pec/depep/spread/rebc_2014.pdf. 
que foi aplicada nos exercícios quantitativos a simplificação sugerida pelos próprios autores que desenvolveram os testes de screening, que consiste em calcular a "diversion ratio" com base nas informações de participações de mercado. Esse procedimento deve ser adotado apenas se houver um razoável grau de substitutibilidade entre os produtos do mercado.

135. O estudo das Requerentes questiona também a utilização de uma "retention ratio" de 100\%. Foi esclarecido que "a retention ratio pode ser entendida como a porcentagem total de clientes que permanecem no mercado apesar do aumento de preço de determinado produto. Como exemplo para melhor entendimento, uma retention ratio de $100 \%$ indica que caso o banco Bradesco aumente o preço de um determinado produto, todos os clientes que porventura saíssem deste banco seriam alocados nos demais bancos. Já uma retention ratio de $90 \%$ indicaria que $10 \%$ desses clientes sairiam do mercado". À luz de tais esclarecimentos, estou convencido de que o procedimento mais adequado consiste em considerar a "retention ratio" como sendo igual a 100\%, como feito pelo DEE. O motivo para este entendimento é que estamos tratando do setor bancário, cujos produtos e serviços são essenciais à parcela da população que é bancarizada. Ou seja, ante um forte aumento de tarifas ou de taxas de juros por parte de um banco, ou ainda, ante a extinção de um banco por meio de sua absorção por outro, como é o presente caso, parece-me mais provável que seu cliente necessariamente irá trocar de instituição ao invés de sair do mercado. Sair do mercado aqui significaria encerrar sua conta e suspender suas transações financeiras em toda e qualquer instituição bancária. É pouco factível que os clientes parem de demandar produtos e serviços bancários devido a elevação de preço de uma das instituições do mercado, sendo mais provável que desviem sua demanda quando a elevação de preços atinge determinado patamar.

136. Também a margem de lucro utilizada foi alvo de crítica por parte das Requerentes, tanto no que diz respeito ao valor atribuído (30\%) quanto à simplificação de que a rentabilidade é a mesma para todos os produtos analisados. Como antes ressaltado, a questão da margem de lucro é crucial nos testes de screening. Sobre esse ponto, reafirmo minha premissa de privilegiar o uso da melhor informação neutra disponível sobre a margem dos bancos. ${ }^{62}$ Muito embora essa margem não englobe a totalidade dos produtos e serviços oferecidos pelos bancos, ela se refere à atividade privativa e primordial dos

62 Relatório de Economia Bancária e Crédito 2014. Disponível em http://www.bcb.gov.br/pec/ depep/spread/rebc_2014.pdf. 
bancos: a intermediação financeira. Antes de constituir uma fragilidade metodológica, a utilização dessa margem de 30\% é um ponto que fortalece a presente análise, pois, como veremos adiante, os mercados que restarão como problemáticos ao fim de nossa análise guardam, em sua maioria, estreita relação com a intermediação financeira, de forma que haveria um viés em utilizar uma margem genérica, que levasse em conta todos os produtos e serviços ofertados pelos bancos.

137. Por fim, quanto à crítica de que a utilização da "divertion ratio" na direção do impacto sobre o "produto HSBC" seria inapropriada, tendo em vista que esse produto será descontinuado ou retirado do mercado e que todos os clientes HSBC passarão a utilizar a estrutura de serviços do Bradesco, considero-a parcialmente improcedente. De fato, se admitirmos que o produto será mesmo descontinuado, não sendo prestado um serviço de qualidade diferenciada aos atuais clientes do HSBC, devemos reconhecer que o resultado do teste, em termos numéricos, refletirá uma pressão de preços sobre um produto que deixará de existir, e isso pode não ter uma interpretação direta e intuitiva. Há que se questionar, no entanto, se de fato o "produto HSBC" será descontinuado. As Requerentes alegam que o principal motivo da operação é expandir a atuação do Bradesco no seguimento "prime", que é o nicho de mercado explorado atualmente pelo HSBC. Assim, poderíamos classificar o "produto HSBC" como um nicho ou segmento de mercado que continuará sendo explorado pelo Bradesco, e que é fundamentalmente distinto da média do "produto Bradesco", em aspectos como qualidade e agilidade do atendimento, exclusividade, confiança, segurança etc.

138. Mas mesmo que acreditemos que não haverá de fato uma distinção entre os produtos após o ato de concentração, ou seja, mesmo considerando que o atendimento destinado a clientes de alta renda (típicos clientes do HSBC) será descontinuado por completo, considero que qualquer resultado do teste será necessariamente inferior à real pressão de preços sobre o produto em análise, uma vez que a descontinuidade desse produto pode ser interpretada como um aumento de preços tão violento que ele ultrapassaria a reserva de valor de todos os consumidores do mercado, criando o pior cenário possível em termos de perda de bem-estar. Em outras palavras, a retirada do produto do mercado significa que nem o consumidor com maior disponibilidade a pagar por esse produto teria condições de adquiri-lo, e isso equivaleria a um aumento estratosférico de preços. Portanto, ainda que o valor absoluto do teste possa não ter uma interpretação tradicional, ele aponta na direção exata do efeito da operação sobre o bem-estar dos consumidores. 


\section{VI.4 Probabilidade de Exercício de Poder de Mercado}

139. A mera possibilidade de exercício de poder de mercado (inferida a partir de testes quantitativos e de percentuais de participação de mercado) não significa que tal poder vá necessariamente ser exercido pelas Requerentes. Por esse motivo, a avaliação de atos de concentração requer, na sequência, uma análise quanto à probabilidade de exercício do poder de mercado em função da possibilidade de: (i) entrada de novos ofertantes; (ii) rivalidade oferecida pelas empresas já estabelecidas; e (iii) poder coordenado.

140. Conforme tratado no capítulo que analisa o mercado bancário de modo geral, compartilho das considerações constantes do Parecer Técnico no 12/2016/CGAA02/SGA1/SG (SEI 0183985), que, após discutir amplamente tais questões, considerou que:

a. A entrada de uma nova empresa nesse mercado não poderia ser considerada como provável, tempestiva e suficiente, tendo em vista os custos irrecuperáveis, a fidelidade dos consumidores às marcas estabelecidas, as fortes economias de escala e de escopo e a existência de barreiras legais e regulatórias.

b. A rivalidade é baixa em função do efeito "lock-in" criado pela forte assimetria de informação e alto custos de transação para se migrar de um banco para outro, tais como histórico de crédito, quitação de financiamentos em aberto etc.

c. O poder coordenado é facilitado pela elevada concentração nas mãos de poucos agentes, cujas participações de mercado são bastante simétricas, além do alto nível de interação entre eles, em inúmeras instâncias de associação de classe. Reforça essa percepção o quadro apresentado acima com todas as condutas atualmente sob investigação no setor bancário brasileiro.

141. De modo geral, faço apenas uma observação adicional quanto às barreiras à entrada no setor bancário. As Requerentes mencionaram a atuação dos correspondentes bancários como um mecanismo mitigador dos custos de entrada nos mercados locais. ${ }^{63}$ Com efeito, trata-se de um meio

63 Conforme Bacen (Resolução CMN 3.954/2011):

Que serviços os correspondentes podem oferecer? 
menos oneroso para que as mesmas grandes instituições possam ofertar seus produtos em regiões antes não atendidas. Entretanto, a entrada em nível local nunca foi categorizada como improvável em função de altos custos afundados para se instalar e manter um equipamento funcionando na localidade. Seja uma agência, seja um terminal eletrônico, os custos dessas facilidades são relativamente baixos e não específicos. Ou seja, em caso de fracasso comercial, não há elevados custos afundados. A entrada não ocorre, a meu ver, pela dificuldade de se capturar clientes de outros bancos já instalados, ou seja, é uma decorrência do próprio efeito de "lock-in" típico do setor bancário. Os correspondentes bancários são inegavelmente úteis em termos de prestação de serviços para clientes de outros municípios que precisam realizar transações em uma determinada localidade onde se encontram momentaneamente (em viagem de férias ou a trabalho, por exemplo), mas seriam inócuos no sentido de exercer pressão efetiva. Assim, entendo que esse tipo de entrada no mercado não tende a ser suficiente para disciplinar o poder de mercado das empresas já estabelecidas.

Depende do que tiver sido contratado com a instituição financeira. A regulamentação permite oferecer os serviços listados abaixo:

a. recepção e encaminhamento de propostas de abertura de contas de depósitos à vista, a prazo e de poupança mantidas pela instituição contratante;

b. realização de recebimentos, pagamentos e transferências eletrônicas visando à movimentação de contas de depósitos de titularidade de clientes mantidas pela instituição contratante;

c. recebimentos e pagamentos de qualquer natureza, e outras atividades decorrentes de contratos e convênios de prestação de serviços mantidos pela instituição contratante com terceiros (água, luz, telefone, etc.);

d. execução ativa e passiva de ordens de pagamento cursadas por intermédio da instituição contratante por solicitação de clientes e usuários;

e. recepção e encaminhamento de propostas referentes a operações de crédito e de arrendamento mercantil de concessão da instituição contratante;

f. recebimentos e pagamentos relacionados a letras de câmbio de aceite da instituição contratante;

g. recepção e encaminhamento de propostas de fornecimento de cartões de crédito de responsabilidade da instituição contratante;

h. serviços complementares de coleta de informações cadastrais e de documentação, bem como controle e processamento de dados;

i. realização de operações de câmbio de responsabilidade da instituição contratante, relativamente a:

i.1. compra e venda de moeda estrangeira em espécie, cheque ou cheque de viagem, bem como carga de moeda estrangeira em cartão pré-pago, limitadas ao valor equivalente a US\$3 mil dólares dos Estados Unidos por operação;

i.2. execução ativa ou passiva de ordem de pagamento relativa a transferência unilateral do ou para o exterior limitada ao valor equivalente a US\$ 3 mil dólares dos Estados Unidos por operação; e

i.3. recepção e encaminhamento de propostas de operações de câmbio. 
142. Assim, de uma forma geral, não tenho grandes reparos a fazer sobre o entendimento da SG quanto à probabilidade de exercício de poder de mercado no setor bancário como um todo, tendo reproduzido e complementado esse entendimento de forma satisfatória em momento anterior do voto. Contudo, conforme alegaram as Requerentes de modo acertado, tais considerações foram tecidas de forma ampla e genérica, olhando para os produtos e serviços bancários de forma agregada e em nível nacional. Tendo em vista que o mercado relevante foi definido produto a produto e em nível municipal, cabe neste ponto verificar se não seria o caso de haver baixas barreiras à entrada e forte rivalidade, em nível local, para o caso dos produtos que ainda despertam preocupações concorrenciais. É o que faço a seguir.

\section{VI.4.1 Mercado de Cobrança com Registro - Aspectos Específicos}

143. Embora possa haver clientes interessados estritamente nesse tipo de produto, do ponto de vista da oferta não é possível realizar uma entrada somente no mercado de cobrança bancária, que é específica do portfólio das instituições bancárias. Portanto, mesmo a nível local, permanece o mesmo diagnóstico elaborado pela Superintendência-Geral: elevados custos irrecuperáveis, fidelidade dos consumidores às marcas estabelecidas, fortes economias de escala e de escopo e existência de barreiras legais e regulatórias.

144. Não há evidências de que haja empresas de atuação local capazes de disciplinar um eventual exercício de poder de mercado por parte das Requerentes, pois o produto é comercializado apenas por instituições bancárias, de forma que não é possível ao cliente contratá-lo de forma avulsa, sem vínculo com uma conta-corrente. Foi informado pelas Requerentes, ${ }^{64}$ inclusive, que diversos bancos de pequeno e médio porte, quando vendem esse produto aos clientes, recorrem aos grandes bancos para conseguir fornecer o serviço aos seus clientes. ${ }^{65}$ Por fim, ao contrário do que foi alegado pelas Requerentes, não se trata exatamente de um produto restrito a grandes empresas, pois muitos clientes menores se utilizam da cobrança bancária para

64 Considerações ao Despacho do Conselheiro-Relator (SEI 0203119).

65 Por esse motivo, os dados de participação de mercado não corresponderiam à realidade concorrencial do mercado desse produto. Segundo informado pelas Requerentes, no caso do Bradesco, cerca de 1/3 do valor total emitido são referentes a emissão de boletos em nome de outros bancos. Além disso, o volume da cobrança sem registro, para a qual não há dados de mercado disponíveis, seria significativo. 
arrecadar pequenos valores. Por esses motivos, tenderíamos a dar continuidade à análise desse produto, mantendo-o no rol de mercados problemáticos.

145. Contudo, entendo que há produtos substitutos suficientemente próximos que atenuam em grande medida a probabilidade de exercício de poder de mercado. Refiro-me às alternativas de recebimento de valores por meio de cheque, por transferência bancária e por cartão de crédito (que será analisado a seguir), comumente usados pelas empresas de diversos portes para receber os valores que lhe são devidos. Além disso, me pareceu razoável o argumento das requerentes de que os dados podem estar poluídos, gerando viés de sobrestimação do poder de mercado do Bradesco, em decorrência do fato de outros bancos menores terceirizarem a operação de cobrança bancária para os maiores bancos.

146. Portanto, entendendo haver rivalidade suficiente para coibir uma pressão de preços nesse mercado em particular, a análise deste produto será descontinuada.

\section{VI.4.2 Mercado de Empréstimo em Moeda Estrangeira - Aspectos Específicos}

147. Do ponto de vista da oferta, não é possível entrar no mercado ofertando somente esse tipo de produto, específico do portfólio das instituições bancárias por ser de intermediação financeira. Assim, permanece o mesmo diagnóstico elaborado pela Superintendência-Geral em termos de entrada: elevados custos irrecuperáveis, fidelidade dos consumidores às marcas estabelecidas, fortes economias de escala e de escopo e existência de barreiras legais e regulatórias.

148. Contudo, o mercado geográfico desse produto certamente é bem mais amplo que o municipal, podendo chegar inclusive a ser internacional para o caso de grandes empresas importadoras e/ou exportadoras, ${ }^{66}$ capazes de suportar os "switching costs", característicos do setor bancário, devido ao seu porte e à maior facilidade que têm para manter relacionamento comercial com diversas instituições simultaneamente, de forma que lhes é possível pesquisar e barganhar por melhores condições nas negociações, normalmente de grande vulto.

${ }_{66}$ Segundo as Requerentes, $89 \%$ do volume de operações são fechados com empresas grandes (SEI 0203119). 
149. Mesmo para clientes de menor porte, o mercado poderia ser considerado como nacional, pois os principais bancos operam esses produtos a partir de centrais que cobrem macrorregiões do território nacional. Assim, clientes de pequeno e médio porte também sofrem menos as consequências das assimetrias de informação e, portanto, estão menos sujeitos ao poder de mercado dos bancos em nível local.

150. Dessa forma, parece haver um nível de rivalidade não desprezível também nesse mercado, motivo pelo qual a análise do produto será descontinuada.

\section{VI.4.3 Mercado de Cartão de Crédito - Aspectos Específicos}

151. As Requerentes argumentaram que nesse mercado há emissores de cartões "private lable", presentes no país inteiro, que sequer dependem de um banco ou estrutura de agências para serem comercializados, sendo vinculados a outros tipos de negócios, que não bancos, como redes de lojas de varejo, por exemplo.

152. Reconheço que os fatores acima reduzem consideravelmente as barreiras à entrada nesse mercado. De fato, conforme as normas do Banco Central, não é necessário ser instituição financeira para atuar no mercado de emissão de cartões de crédito. ${ }^{67}$ Essas características suportam uma definição mais ampla da dimensão geográfica do mercado relevante, até porque a contratação e ativação de um cartão de crédito pode ser realizada de forma remota, pela internet em conjunto com os correios, por exemplo. Além disso, há elementos que denotam considerável grau de rivalidade no mercado de emissão de cartões de crédito, como a oferta por telefone e de condições diferenciadas para conquistar e/ou reter os clientes, como, por exemplo, a isenção da taxa de anuidade, a depender do nível de utilização do produto.

153. Portanto, entendo haver rivalidade suficiente para coibir eventuais pressões de preços, motivo pelo qual a análise deste produto será descontinuada. 67 Vide “Emissor de instrumento de pagamento pós-pago" em http://www.bcb.gov.br/pre/
composicao/instpagamento.asp. 


\section{VI.4.4 Mercado de Crédito de Livre Utilização PF e PJ - Aspectos Específicos}

154. Mesmo a nível local, pode-se sustentar o mesmo diagnóstico elaborado pela Superintendência-Geral: elevados custos irrecuperáveis, fidelidade dos consumidores às marcas estabelecidas, fortes economias de escala e de escopo e existência de barreiras legais e regulatórias.

155. De fato, reconheço que nesse mercado pode haver bancos estaduais e regionais, cooperativas de crédito de atuação local, financeiras, e bancos de pequeno e médio porte especializados em nichos específicos de mercado. Não podemos ignorar que essas instituições exercem alguma pressão competitiva e influenciam, mesmo que parcialmente, na definição das condições praticadas pelos grandes bancos. Por isso, entendo que, permanecendo o problema, esse mercado tem que ser analisado município a município, pois um banco menor ou uma financeira presente em um determinado município podem não estar presente em outro. Essa filtragem é feita na sessão derradeira deste voto, que trata da aplicação de remédios comportamentais específicos para mercados problemáticos.

\section{VI.4.5 Mercado de Depósitos à Vista - Aspectos Específicos}

156. O depósito à vista pode ser considerado como uma variável proxy para o mercado do produto "conta corrente". Nas palavras das próprias Requerentes, "Depósito à vista não é um produto em si próprio, sendo indissociável do relacionamento do cliente com seu banco. Em outras palavras, o depósito à vista funciona como um hub financeiro que serve como plataforma para a realização de transações financeiras decorrentes da oferta de produtos bancários". Esse é o principal produto bancário, e é uma atividade específica e exclusiva de bancos comerciais, não havendo substitutos próximos ou agentes especializados em nichos de mercado, como nos casos anteriores. Portanto, mesmo a nível local, permanece o mesmo diagnóstico elaborado pela Superintendência-Geral e discutido anteriormente: elevados custos irrecuperáveis, fidelidade dos consumidores às marcas estabelecidas, fortes economias de escala e de escopo e existência de barreiras legais e regulatórias.

157. Assim, não vislumbramos qualquer justificativa para que esse mercado seja descartado como problemático, mas concordamos que qualquer 
eventual restrição imposta a esse mercado deve levar em consideração a dimensão geográfica local da definição do mercado relevante, e assim o faremos, novamente, na seção final do voto, que trata da aplicação de remédios.

\section{VI.4.6 Conclusões sobre Probabilidade de Exercício de Poder de Mercado}

158. Portanto, tendo em vista os aspectos relacionados à análise de rivalidade, considero como provável o exercício de poder de mercado por parte das Requerentes nos produtos: i) depósito à vista, ii) crédito de livre utilização PJ, e iii) crédito de livre utilização PF. Sendo assim, passaremos a discutir doravante as eficiências requeridas para anular as prováveis pressões de elevação nos preços nos mercados problemáticos do ponto de vista concorrencial.

\section{Das eficiências}

159. Em 3 de maio de 2016, por meio de petição (SEI 195129), as Requerentes instruíram nos autos o documento "Eficiências Econômicas da Operação Bradesco - HSBC", de lavra da LCA Consultores, que descreve as eficiências e sinergias a serem alcançadas com o presente ato de concentração, conforme solicitação deste Gabinete por meio do Ofício nํㅗ 1918/2016/CADE (SEI 189115). Posteriormente, em 23 de maio de 2016, os autos foram instruídos com informações relativas a eficiências adicionais por meio do documento Considerações ao Despacho do Conselheiro Relator (SEI 0203119).

160. Para a análise das eficiências apresentadas, adotarei a prática usual refletida no Guia de Concentrações Horizontais atualmente vigente, e que foi muito bem aplicada no Ato de Concentração 08012.004423/2009-18 (Perdigão S.A. e Sadia S.A.), de relatoria do Conselheiro Carlos Emmanuel Joppert Ragazzo. O Guia admite como eficiências passíveis de anular prováveis aumentos de preços aquelas que atendam, cumulativamente, aos seguintes critérios:

a. Sejam quantificáveis;

b. Sejam demonstráveis, e não puramente especulativas;

c. Sejam intrínsecas e específicas da operação em análise;

d. Que não sejam meras transferências de renda entre agentes; 
e. Que estejam relacionadas aos custos variáveis da empresa;

f. Que possam ser atingidas em até dois anos.

161. Ou seja, nem toda eficiência, ganho ou sinergia, vulgarmente entendida como algo que traga benefício para algum agente econômico, traduzse em eficiência sob a óptica antitruste. Segundo o enfoque concorrencial, as eficiências que interessam para as análises de pressão de preços são especificamente aquelas que tornam possível o repasse de benefícios decorrentes da operação aos consumidores finais, seja na forma de redução de preços ou na forma de melhoria da prestação do serviço ao mesmo preço cobrado antes da operação.

162. Após minuciosa análise de cada item apresentado pelas Requerentes, tendo como parâmetro os critérios acima, este Gabinete concluiu que, do montante de [ACESSO RESTRITO ÀS REQUERENTES] de eficiências inicialmente alegadas, a serem alcançadas ao longo dos quatro anos seguintes à aprovação da operação, apenas [ACESSO RESTRITO ÀS REQUERENTES] poderiam ser para os fins da presente análise. Já em relação às eficiências informadas no segundo momento, do total de [ACESSO RESTRITO ÀS REQUERENTES] alegados, puderam ser aceitas somente [ACESSO RESTRITO ÀS REQUERENTES].

Tabela 11

Análise de Eficiências

\begin{tabular}{|c|c|c|}
\hline Eficiências Apresentadas & Avaliação das Eficiências & Resultado (R\$ milhões) \\
\hline $\begin{array}{l}\text { [ACESSO RESTRITO ÀS } \\
\text { REQUERENTES] }\end{array}$ & Aceitas, cumulativamente até o ano 2 & $\begin{array}{l}\text { [ACESSO RESTRITO ÀS } \\
\text { REQUERENTES] }\end{array}$ \\
\hline $\begin{array}{l}\text { [ACESSO RESTRITO ÀS } \\
\text { REQUERENTES] }\end{array}$ & $\begin{array}{l}\text { Não intrínseca à operação } \\
\text { Mera transferência de renda } \\
\text { Não afeta custo variável } \\
\text { Não quantificável }\end{array}$ & \\
\hline $\begin{array}{l}\text { [ACESSO RESTRITO ÀS } \\
\text { REQUERENTES] }\end{array}$ & $\begin{array}{l}\text { Não intrínseca à operação } \\
\text { Não afeta custo variável }\end{array}$ & \\
\hline $\begin{array}{l}\text { [ACESSO RESTRITO ÀS } \\
\text { REQUERENTES] }\end{array}$ & $\begin{array}{l}\text { Não intrínseca à operação } \\
\text { Não afeta custo variável }\end{array}$ & \\
\hline $\begin{array}{l}\text { [ACESSO RESTRITO ÀS } \\
\text { REQUERENTES] }\end{array}$ & Não afeta custo variável & \\
\hline $\begin{array}{l}\text { [ACESSO RESTRITO ÀS } \\
\text { REQUERENTES] }\end{array}$ & Não afeta custo variável & \\
\hline $\begin{array}{l}\text { [ACESSO RESTRITO ÀS } \\
\text { REQUERENTES] }\end{array}$ & Aceitas, cumulativamente até o ano 2 & $\begin{array}{l}\text { [ACESSO RESTRITO ÀS } \\
\text { REQUERENTES] }\end{array}$ \\
\hline TOTAL & & $\begin{array}{l}\text { [ACESSO RESTRITO ÀS } \\
\text { REQUERENTES] }\end{array}$ \\
\hline
\end{tabular}

* Eficiências posteriormente informadas 
163. Assim, pelas razões constantes no quadro, aceitei admitir como montante de economia de custos decorrente das eficiências próprias da operação e potencialmente repassáveis aos consumidores finais o valor de [ACESSO RESTRITO ÀS REQUERENTES] milhões de reais em dois anos (média de [ACESSO RESTRITO ÀS REQUERENTES] ao ano). Em outras palavras, meu entendimento é de que o Bradesco será capaz de prestar os mesmos serviços aos atuais clientes do HSBC a um custo variável total [ACESSO RESTRITO ÀS REQUERENTES] inferior ao custo atualmente incorrido pelo HSBC em dois anos.

164. Para fins de utilização desse valor em testes quantitativos que permitam avaliar o impacto dessas eficiências no resultado do mercado pós-operação, é necessário proporcionalizar esse montante em relação ao total dos custos variáveis da empresa, que são justamente aqueles cujas reduções são passíveis de serem repassadas aos consumidores finais em termos de preço.

165. Para tanto, foram construídos dois cenários, um que considera os custos segundo o Demonstrativo de Resultado do Exercício do HSBC (controladora) relativo ao ano de 2014 (mesmo ano base utilizado para cálculo das eficiências), e outro que leva em conta os números apresentados pelo HSBC ao Banco Central do Brasil, segundo a padronização do Plano Contábil das Instituições do Sistema Financeiro Nacional (COSIF). As seguintes premissas foram adotadas em ambos os casos:

a. Rubricas Utilizadas: Despesas de Intermediação Financeira; Despesas de Pessoal; Outras Despesas Administrativas e Outras Despesas Operacionais.

b. Rubricas Descontadas (Custo Fixo): Depreciações e amortizações, Publicidade e propaganda, Promoções e relações públicas, Despesas com contribuições filantrópicas e Outras.

c. Foram somadas as eficiências aceitáveis relativas aos dois primeiros anos.

d. Os custos anuais foram duplicados (para efeito de comparação com os 2 anos de eficiências aceitas).

e. Utilizamos os dados de custo do HSBC, desprezando os custos do Bradesco, uma vez que as Requerentes apresentaram eficiências que dizem respeito exclusivamente ao HSBC.

166. Os resultados dos dois cenários foram os seguintes:
a. Cenário DRE (HSBC): 5,1\%
b.Cenário COSIF (HSBC): 2,1\% 
167. Para efeito de comparação desses percentuais de eficiências sobre os custos variáveis com a quantidade de eficiências necessárias para anular os incentivos à elevação de preços pelas Requerentes nos produtos identificados como problemáticos, utilizamos a metodologia do teste UPP (Upward Pricing Pressure), conforme artigo seminal de Farrel e Shapiro (2010). ${ }^{68}$ Esse teste, embora originalmente desenvolvido para ser usado como screening, também permite verificar se, após alcançadas as eficiências apresentadas e aceitas, ainda assim haverá pressão de alta sobre preços.

168. Quando assumimos o cenário mais favorável às Requerentes (eficiências de 5,1\%), obtemos os resultados constantes da tabela abaixo, os quais indicam que, mesmo que as Requerentes alcancem as eficiências pretendidas em dois anos, ainda assim haverá pressão de alta nos preços para os três produtos que remanescem como preocupações concorrenciais decorrentes da operação.

Tabela 12

Resultado UPP (assumindo 5,1\% de eficiências)

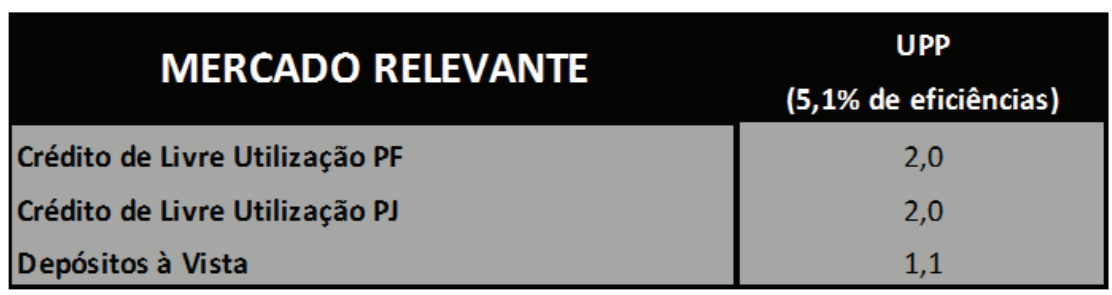

169. O teste UPP nos permite, ainda, inferir o montante de eficiências requeridas para anular a pressão de aumento de preços em cada produto. Em outras palavras, podemos estimar o quanto de eficiências, como percentual do custo variável, seria necessário para que o resultado do teste fosse nulo. Aqui também é possível construir dois cenários: o primeiro considerando a forma algébrica utilizada tradicionalmente, conforme utilizado pelo DEE na Nota Técnica no 09/2016/DEE/CADE; e o segundo considerando produtos diferenciados, tal como detalhado em Werden (1996). ${ }^{69}$ Essas duas medidas

68 Joseph Farrell and Carl Shapiro (2010) "Antitrust Evaluation of Horizontal Mergers: An Economic Alternative to Market Definition," The B.E. Journal of Theoretical Economics: Vol. 10: Iss. 1 (Policies perspectives), Article 9.

69 Werden, A Robust Test for Consumer Welfare Enhancing Mergers Among Sellers of Differentiated Products, 44 J. INDUS. ECON. 409 (1996). 
de eficiências críticas estabelecem o intervalo dentro do qual as eficiências deveriam se situar, percentualmente, para dirimir os prováveis efeitos nocivos da operação nos produtos em questão. O resultado é apresentado a seguir:

Tabela 13

Eficiências Críticas Requeridas para Anular UPP

\begin{tabular}{|l|c|c|}
\hline \multicolumn{1}{|c|}{ MERCADO RELEVANTE } & $\begin{array}{c}\text { UPP - Modelo tradicional } \\
\text { (mínimo) }\end{array}$ & $\begin{array}{c}\text { UPP - Produtos diferenciados } \\
\text { (máximo) }\end{array}$ \\
\hline Crédito de Livre Utilização PF & $8,0 \%$ & $9,8 \%$ \\
Crédito de Livre Utilização PJ & $7,9 \%$ & $9,7 \%$ \\
Depósitos à Vista & $6,7 \%$ & $7,9 \%$ \\
\hline
\end{tabular}

170. Como vemos, mesmo assumindo o melhor cenário em favor das Requerentes, o percentual de eficiências se encontra aquém do mínimo necessário para anular a pressão de elevação de preços nos produtos apontados como problemáticos do ponto de vista concorrencial.

171. Como é sabido, os resultados do teste de UPP, em tese, representam uma mera possibilidade de exercício de poder de mercado. Contudo, após vencidas as etapas de análise da probabilidade de exercício de poder de mercado e das eficiências decorrentes da operação, entendo que esses três produtos que ainda assim despontam como capazes de reduzir o bem-estar dos consumidores constituem um problema concorrencial concreto, mensurado pela dimensão dos resultados dos testes.

172. Isso posto, abro aqui um breve "parêntese" para responder a uma crítica específica formulada pelas Requerentes quanto à mensuração das eficiências requeridas, qual seja, "o Conselheiro aplicou ainda um teste chamado de Teste de Werden (1996), pouco usual na literatura e na jurisprudência, para calcular as eficiências necessárias para anular pressões de preço. Tanto no conceito como na mecânica, esse teste é muito semelhante ao GUPPI. (...) A fórmula de cálculo utilizada no teste do Conselheiro-relator é uma simplificação útil para os casos em que as duas firmas 'testadas' são simétricas, ou seja, têm mesmo share e a mesma margem. No caso em que os dois shares não são iguais, deve-se utilizar uma outra fórmula, mais completa, considerando a migração de consumidores nos dois sentidos (do produto 1 para o produto 2 e vice-versa). O viés provocado pela simplificação utilizada pelo conselheiro é significativo e vai no sentido de majorar a indicação do tamanho das eficiências necessárias".

173. Em primeiro lugar, estou ciente de que a fórmula trazida em Werden (1996) constitui uma simplificação para o caso de modelo linear simétrico. 
Por esse motivo o valor obtido como resultado do teste não está sendo empregado de forma arbitrária como sendo o valor de corte para estabelecer o nível de eficiências requeridas. Em vez disso, o valor desse teste é utilizado como limite superior para a construção de um intervalo mínimo para uma linha de corte aceitável. A restrição ativa, no caso em tela, é ainda os valores obtidos com a formatação padrão do teste. Ou seja, da forma como foi empregado, o teste Werden (1996) já contempla a devida flexibilização necessária por se tratar de uma simplificação, pois as eficiências mínimas a serem atingidas são menores, como vemos claramente na última tabela apresentada.

174. Foi argumentado pelas Requerentes que "os testes empregados foram desenvolvidos para retratar setores industriais, e não se amoldam adequadamente para o setor bancário. Se para os produtos de crédito ainda é possível fazer alguma aproximação que viabilize a utilização dos testes, para os demais produtos sua aplicação torna-se absolutamente distanciada da realidade ${ }^{\prime \prime}{ }^{70}$ Essa é uma crítica que, a princípio, valeria para todos os testes aqui aplicados. Discordo dessa compreensão. Naturalmente o teste pode ser mais preciso quando utilizado para um bem industrial clássico, mas não vislumbro razões específicas de por que não poderia ser aplicado a casos no setor de serviços. As razões trazidas para alguns produtos específicos, como a ausência de preços para depósitos à vista, já foram enfrentadas satisfatoriamente acima. Por fim, é certo que existem modelos de simulação mais sofisticados para apurar as possíveis elevações de preços nos cenários pós-fusão por parte das Requerentes, como, por exemplo, o PC-AIDS. ${ }^{71}$ Entretanto, tal metodologia exigirá a estimação de elasticidades para todos os mercados de produto identificados, procedimento inviável dado o exíguo tempo disponível para a presente análise. Além disso, deve-se sempre ponderar a relação custo/benefício de uma análise quantitativamente mais aprofundada. No presente caso, a utilização do modelo UPP foi suficiente para mensurar o nível de eficiência requerido para anular as pressões de preços esperadas nos mercados de produto específicos, independentemente de qual venha ser esse aumento previsto de preços, seja em termos absolutos ou relativos.

175. Frente aos resultados obtidos com a análise das eficiências, entendo serem necessários remédios específicos para mitigar os prováveis efeitos concorrencialmente negativos decorrentes da operação com relação aos

70 Considerações ao Despacho do Conselheiro-Relator (SEI 0203119).

71 PC-AIDS (Proportionally-Calibrated Almost Ideal Demand System). 
produtos: i) depósito à vista, ii) crédito de livre utilização PJ, e iii) crédito de livre utilização PF.

\section{Dos remédios}

176. A Superintendência-Geral submeteu a esse Tribunal pedido de aprovação da presente operação condicionada à imposição de remédios comportamentais, distribuídos em quatro eixos, os quais eu reproduzo abaixo de forma resumida:

a) Transparência e Comunicação

- Ampliar a visibilidade do conteúdo sobre portabilidade no site do Bradesco.

- Criar link no site do Bradesco para o site do cadastro positivo.

- Disponibilizar, na plataforma de acesso virtual dos clientes, extrato de utilização de serviços.

- Criar link de acesso a site da FREBRABAN com comparativo de tarifas bancárias.

- Disponibilizar cartilha sobre portabilidade nas agências de 134 municípios.

- Criar link para educação financeira na primeira página do site do Bradesco.

b) Treinamento

- Incluir módulo de portabilidade nos cursos para funcionários.

- Ampliar a presença de funcionários nos cursos.

- Incluir módulo relativo a qualidade do atendimento nos cursos.

c) Indicadores de Qualidade

- Aumentar o peso dos quesitos de qualidade no programa interno de avaliação dos funcionários.

- Reduzir a participação das reclamações contra o Bradesco originárias de 134 municípios, considerados críticos em relação ao total de reclamações, de $2,1 \%$ para $1,5 \%$.

d) Compliance

- Aderir ao guia de compliance do CADE.

177. Tais exigências são, a meu ver, relevantes e oportunas, e tentam enfrentar o que muitos estudos identificam como o principal problema no setor: a dificuldade existente para que os consumidores de serviços bancários busquem concorrentes, comparem preços e eventualmente migrem para um 
outro banco com melhores condições de prestação do serviço (inclusive por meio do exercício de seu direito à portabilidade). As medidas listadas acima têm o condão de retirar parte das dificuldades que enfrentam os consumidores, e, assim, entendo como oportuno incorporá-las ao ACC a ser firmado com o Bradesco, com pequenas alterações que facilitem sua implementação e seu monitoramento, na forma da minuta de acordo anexa a esse voto.

178. Ainda assim, entendo que esses remédios são insuficientes para enfrentar os problemas concorrenciais dos mercados identificados nesta análise, tanto os problemas específicos quanto a preocupação geral com o grau de concentração que vem assumindo o setor. Conforme já discutido, a instrução complementar realizada no Gabinete 01, ao longo dos últimos dois meses, corroborou as preocupações da Superintendência-Geral em relação ao mercado bancário como um todo, principalmente no que tange à carência de rivalidade entre os agentes do setor, em função, muito provavelmente, da natureza da relação entre os clientes e os bancos comerciais, eivada de assimetria de informação e de custos de transação. Além disso, foram identificados problemas concorrenciais decorrentes da operação nos mercados relevantes: i) oferta de crédito livre para pessoas físicas; ii) oferta de crédito livre para pessoas jurídicas; e iii) depósitos à vista (proxy para a contratação de serviços básicos de conta corrente). Os remédios propostos pela SG são genéricos e estão associados à disseminação de "boas práticas", requerendo, a meu ver, alguns aprimoramentos ${ }^{72}$ para que possam conter minimamente os efeitos indesejáveis da presente operação, dado que as eficiências são insuficientes para anular a provável alta nos preços nesses mercados.

179. Portanto, em resumo, entendo que o conjunto inicial de remédios:

a.Não enfrenta a preocupação geral e crescente deste Conselho (incluindo a própria Superintendência-Geral) com relação ao contínuo processo de concentração do setor bancário brasileiro nas mãos de quatro ou cinco grandes instituições, principalmente considerando que duas delas são bancos públicos;

b.Não enfrenta os problemas específicos identificados nos mercados relevantes acima mencionados.

72 Por exemplo, me parece que a baixa qualidade (excesso de reclamações) dos serviços bancários não decorre exatamente da falta de treinamento dos funcionários, mas essencialmente dos baixos incentivos para que os bancos adotem qualquer estratégia voltada a retirar clientes de seus concorrentes, tendo em vista o efeito "lock-in" e os altos custos de transação existentes no mercado. 
180. Em função disso, esta Relatoria empreendeu esforços para negociar dois outros remédios que atacariam diretamente essas duas questões remanescentes.

\section{VIII.1 Da Obrigação de Não Comprar}

181. O primeiro deles consiste na obrigação do Bradesco de não adquirir o controle, por meio de fusões ou aquisições, de qualquer outra instituição financeira e/ou administradora de consórcio que opere no mercado brasileiro pelos próximos 30 meses (2,5 anos), contados da data de assinatura do Acordo de Controle de Concentrações anexo a esse voto.

182. Essa medida cumpre o objetivo de conter, ainda que no curto prazo, o avanço daquele que muito provavelmente se tornará o terceiro maior banco comercial (em total de ativos) operando no mercado brasileiro, e emite um sinal contundente para o setor bancário sobre a preocupação da autoridade concorrencial com o grau de concentração que ele vem adquirindo. Tal medida permitirá que instituições menores encontrem um ambiente menos hostil para crescerem, mesmo que via aquisições, e adquirirem uma escala suficiente para concorrer com os cinco grandes bancos. Vale lembrar, conforme relataram as próprias Requerentes, o HSBC, sexto maior banco hoje no Brasil, está sendo vendido porque não conseguiu obter o crescimento orgânico que lhe permitisse atingir uma escala viável de competição. Espera-se, assim, que o remédio aplicado ao Bradesco gere externalidades positivas (do ponto de vista concorrencial) para todo o mercado.

183. Importante destacar que essa restrição teve forte cuidado em resguardar as competências do Banco Central do Brasil, como autoridade regulatória setorial, e do Conselho Monetário Nacional, de zelar pela solidez e liquidez do Sistema Financeiro Nacional. Para tanto, contemplou, como exceção à regra de "não comprarás", aquelas operações que o Bacen ou o Conselho Monetário Nacional (CMN) entenderem como necessárias para o cumprimento desse necessário e importante objetivo regulatório. Destaco, ainda, que a redação desse dispositivo guarda estrita observância ao espírito contido no Projeto de Lei no 350/2015, de autoria do Senador Antônio Augusto Anastasia, que atualmente tramita no Congresso Nacional.

184. Ressalto também que tal medida não é inédita no âmbito da defesa da concorrência brasileira, tendo sido aplicada, em maior ou menor grau, nos atos de concentração envolvendo Sadia e Perdigão (AC 08012.004423/2009-10), JBS 
e Rodopa (AC 08700.010688/2013-83) e CSN Usiminas (AC 08012.009198/201121) e no processo administrativo que condenou o famoso cartel do cimento (PA 08012.011142/2006-79). Guarda, portanto, proporcionalidade e razoabilidade ao problema concorrencial identificado e encontra conforto no seu não ineditismo.

\section{VIII.2 Do Incentivo à Portabilidade}

185. Quanto à segunda preocupação concorrencial, relativa àqueles mercados em que a análise empreendida ao longo do processo detectou elevada probabilidade de exercício de poder de mercado, foi inicialmente proposta às Requerentes por esse Gabinete uma medida de "desinvestimento estimulado". A medida tomaria a forma de um desconto a ser oferecido pelo Bradesco, em determinadas localidades, sobre o saldo devedor dos contratos de financiamento contraídos pelos atuais clientes HSBC que, por força do ato de concentração, serão potencialmente absorvidos de forma passiva pelo Bradesco.

186. As localidades seriam, naturalmente, aquelas definidas como mais susceptíveis a pressões de preços ou piora da qualidade na prestação do serviço. Recorrendo à base de dados do Banco Central do Brasil ESTBAN (Estatística Bancária por Município) ${ }^{73}$ que apresenta algumas estatísticas de atividade bancária por município e utilizando como linha de corte o mesmo critério adotado anteriormente para análise de potencial exercício de poder de mercado, qual seja, valor de HHI entre 1.500 e 2.500 pontos e variação do HHI superior a 100 pontos, aplicado sobre a proxy "volume total de captação", identificamos 106 municípios em que a fusão Bradesco e HSBC gerará graus preocupantes de concentração. Assim, a intervenção proposta abarcaria apenas cerca de $20 \%$ dos 523 municípios em que o HSBC atualmente possui agências.

187. Essa medida teria o condão de oferecer um incentivo que pudesse neutralizar em parte os altos custos de transação para mudança de banco (os switching costs) de tais clientes, de modo que eles pudessem, então, procurar concorrentes que oferecessem melhores condições e, eventualmente, viessem a desenvolver um relacionamento comercial mais profundo com essas

73 Disponível em http://www4.bcb.gov.br/fis/cosif/estban.asp (acesso em 27.5.2016). 
instituições. Para evitar que a medida acabasse por gerar maior concentração, tendo em vista o fato de que existem bancos com participação ainda maior que a do Bradesco nesses mercados, o desconto só seria válido para clientes que migrassem para instituições de menor porte. Ainda que inédita e um tanto ousada, tal medida, a meu ver, traria a vantagem de se configurar como uma inserção cirúrgica, focada naqueles pontos críticos da operação. Em outras palavras, possibilitaria a aplicação de um remédio estrutural no setor bancário, uma vez que o principal e indispensável ativo nesse setor é, indiscutivelmente, a carteira de clientes.

188. Nada obstante, as negociações em relação a esse remédio não avançaram em função de dificuldades e riscos operacionais alegados pelo Bradesco para sua implementação. Em contrapartida, o banco se propôs a assumir o compromisso de, para os mesmos clientes pessoas naturais residentes nos mercados relevantes problemáticos, enviar correspondência contendo todas as informações necessárias ao exercício da portabilidade e, ainda, isentar os bancos de menor porte para os quais esses mesmos clientes venham eventualmente a se migrar da cobrança do Custo de Originação, tarifa prevista no regulamento do Banco Central para operações de portabilidade de pessoas físicas. A proposta se limitou aos clientes pessoas naturais, não podendo o benefício ser estendido às pessoas jurídicas em virtude da inexistência de sistemática operacional de portabilidade de contratos de financiamento de pessoas jurídicas e, consequentemente, da ausência de Custo de Originação.

189. Ainda que não necessariamente concorde com os motivos alegados pelo Bradesco para rejeitar a adoção do remédio na forma como originalmente aventada, este Gabinete entendeu que a proposta alternativa, em conjunto com os demais remédios negociados ao longo da instrução do processo na SG e no Gabinete 01, dariam um conforto mínimo para a assinatura do acordo aqui proposto. Cabe ressaltar novamente que, também nesse remédio, resta preservado o princípio da proporcionalidade, sendo ele geograficamente restrito a apenas aqueles municípios onde há maior possibilidade de exercício de poder de mercado pelas Requerentes.

190. Assim sendo, para os produtos de crédito livre, o aprimoramento aqui trazido com relação à proposta inicial de acordo advinda da SG se materializa na forma do compromisso do Bradesco de isenção do Custo de Originação nos casos de portabilidade. Além disso, foi negociado que o Bradesco disponibilizará em seu sítio eletrônico na internet um link específico para acesso dos clientes ao comparativo de taxas de juros do Banco Central "Taxas de 
juros de operações de crédito", como forma de fomentar a transparência e reduzir assimetrias de informação.

191. Quanto ao produto depósitos à vista, que, relembro, é uma proxy para os serviços englobados à conta-corrente, não foi possível negociar um remédio específico com o grau de eficácia desejada, mas entendo que o conjunto de algumas medidas específicas tenderá a lidar suficientemente bem com a questão. Essas medidas são:

a. Foi acrescentado o remédio adicional específico de incluir a informação do custo total das tarifas unitárias no extrato de tarifas, já previsto na minuta inicial do ACC proposto pela SG.

b. A aprovação da operação pelo Banco Central do Brasil foi condicionada à assinatura de um acordo em que o Bradesco se compromete a [ACESSO RESTRITO ÀS REQUERENTES].

c. Por fim, o incentivo para que os clientes pessoas naturais venham a pesquisar e eventualmente efetivar seu direito à portabilidade de contrato de financiamento para outro banco pode ter efeito indireto sobre o mercado de depósito à vista, pois a simples busca de um concorrente permite que este novo banco tente seduzir o cliente a desenvolver uma relação comercial mais profunda com a instituição.

192. Assim, mediante o compromisso das requerentes de assumirem as obrigações elencadas nessa seção por meio de um ACC, trago o voto no sentido de uma aprovação mediante acordo.

\section{Do Acordo em Controle de Concentrações - ACC}

193. Com o objetivo de remediar as preocupações concorrenciais remanescentes, as Requerentes sugeriram aprimorar a minuta do Acordo em Controle de Concentrações - ACC proposto à Superintendência-Geral (SEI 0187688).

194. A versão final do ACC contempla aprimoramentos da versão inicial, bem como os novos remédios específicos destinados a mitigar os problemas concorrenciais identificados ao longo da presente análise, conforme discutido acima. 


\section{Do dispositivo}

195. Ante todo o exposto, voto pelo conhecimento e aprovação da presente operação condicionada à formalização e regular cumprimento do Acordo em Controle de Concentrações - ACC anexo a esta decisão.

\section{X.1 Das Recomendações à Superintendência-Geral}

196. Por fim, em função de tudo que foi discutido neste voto-relator e do conhecimento adquirido ao longo das instruções adicionais realizadas pelo Gabinete 01, recomendo à Superintendência-Geral que, na análise de futuros casos no setor bancário:

1. Assim como o fez no presente AC, e salvo casos excepcionais em que claramente todas as partes Requerentes sejam agentes concorrencialmente inexpressivos, trate os futuros atos de concentração no setor bancário como atos de rito não sumário, restando atenta ao processo de "cherry picking" em curso no setor;

2. Avalie a conveniência de, para fins de simulações e testes quantitativos, considerar os eventuais efeitos concorrenciais derivados do fato de a Caixa Econômica Federal e o Banco do Brasil serem agentes atuantes em um mesmo setor, controlados, ambos, pela União.

3. Alternativamente ao item anterior, avalie a conveniência de excluir ou relativizar o peso da Caixa Econômica Federal nas simulações e testes quantitativos, tendo em vista ser um banco que a) não possui segmento "prime", tendo como base principal de clientes aqueles de menor renda, e b) não tem como finalidade principal, muitas vezes, a maximização de lucro para seus acionistas, inclusive por não ter capital aberto, mas a execução de políticas públicas preconizadas por seu único acionista controlador, a União;

4. Considerando que, por fatores decorrentes da natureza da demanda, o mercado relevante para a maioria dos produtos e serviços oferecidos pelas instituições financeiras, no entender deste Relator, é local, e que dados em nível local estão disponíveis no sistema de informações públicas do Banco Central, ainda que não desagregados completamente para cada produto especificamente, avalie a conveniência de realizar, adicionalmente, análise antitruste em nível local, identificando os 
municípios em que a concorrência possa ser fortemente prejudicada em função de uma nova concentração;

5. Sempre que possível, continue a adotar como filtros adicionais os testes de screening para produtos diferenciados, como fez no presente caso;

6. Insista para que as Requerentes apresentem, tempestivamente, estimativas verificáveis e plausíveis de eficiências decorrentes da operação.

É o voto. 